\title{
NATIONAL EDUCATION ASSOCIATION OF THE UNITED STATES
}

DEPARTMENT OF SUPERINTENDENCE.

\section{Agriculture, Industries, and Home Economics in Our Public Schools}

BY

HON. WILLET M. HAYS

ASSISTANT SECRETARY OF AGRICULTURE

WASHINGTON, D. C.

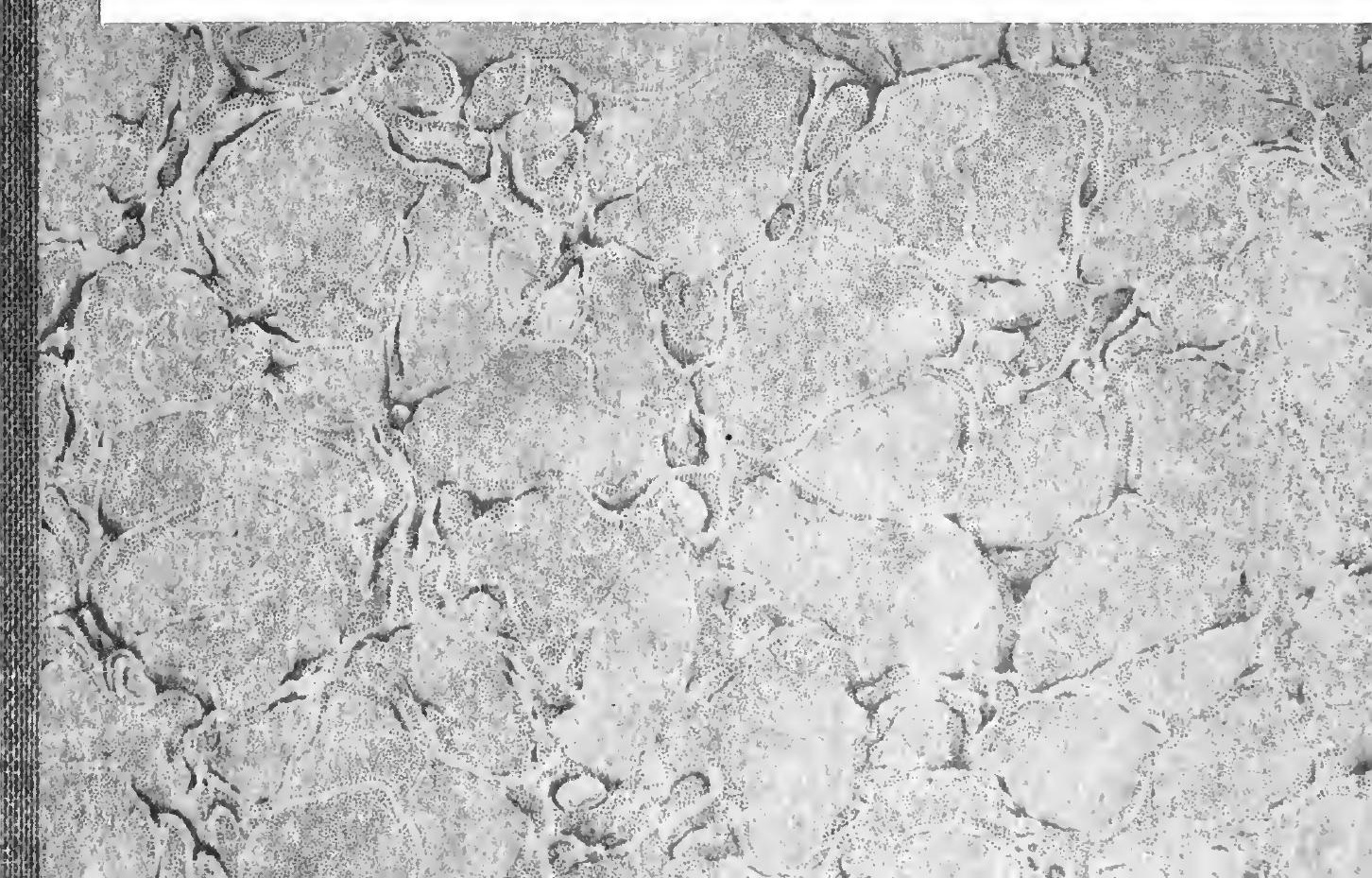




\section{CATIONAL EDUCATION ASSOCIATION OF THE UNITED STATES \\ DEPARTMENT OF SUPERINTENDENCE}

\section{Agriculture, Industries, and Home Economics in Our Public Schools}

BY

HON. WILLET M. HAYS

ASSISTANT SECRETARY OF AGRICULTURE

WASHINGTON, D. C.

UNIVERSITY of CALIFORNL AT

LOS ANGELES

LIBRARY

An address delivered before the Department of Superintendence in

Washington, D. C., February 25, 1908 


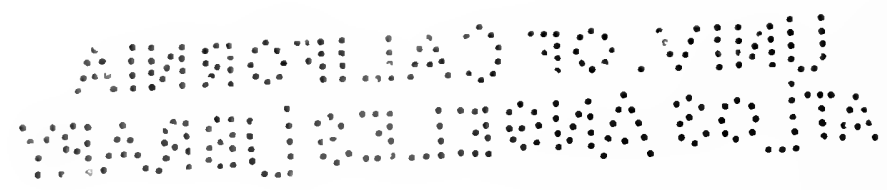

Composed and Printed liy

The University of Chicago Press

Chicago, Illinois, U.S. A. 


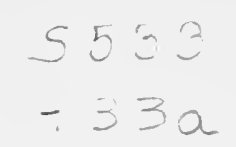

AGRICULTURE, INDUSTRIES, AND HOME ECONOMICS IN OUR PUBLIC SCHOOLS

WILLET M. HAYS, ASSISTANT SECRETARY OF AGRICULTURE, WASHINGTON, D. C.

Our country has come to recognize that changed economic conditions, an increase in technical knowledge, and newly devised forms of school work have made it necessary and practicable to broaden out our educational machinery so as to give a large place to the industrial vocations. Existing schools must enrich their courses of study along these new lines so vitally connected with the thought and work of the people, and the newer types of schools especially fitted to the industrial life of the people must be developed so as to meet the new conditions in the largest and best way. The volume of the new work is very large. No one class of schools can do all of it. The question might be raised whether it is better to adapt existing schools to do this teaching or to develop new schools for this purpose. Manifestly we shall get on all too slowly, even if we utilize both plans.

Generally speaking, one-third of our menfolk are in agriculture, and onethird in the non-agricultural productive industries; while two-thirds of our women are in the vocation of home-making. Thus at least two-thirds of all our people enter the vocations of agriculture, the mechanic industries, and home-making, and nearly all these receive their only schooling in our public schools. The percentage of the whole of our workers engaged in agriculture has decreased in a century from three-fourths of the whole population to one-third, and the indications are that it will decrease to one-fourth. As this percentage decreases the proportions become more nearly static, and those leaving the farm for the city are replaced by those leaving the city for the farm. Under conditions in which only a very small part of the population move from the farm to the town and only an equal number move from the city to the country, the rural community should have for the higher grades in its schools strong vocational courses, and the education for the city youth should close with courses related to the city vocations. There should be also easy methods of transit from the country life schools to the city schools and vice versa. All will agree that there should be in the city schools some agriculture both as a culture-study and as a means of interesting those peculiarly attracted to and adapted for the life of farming or the work of specialists in lines related to agriculture. All will agree, also, that the school in the rural community should have some instruction in mechanics because of its general educational and its vocational value in farming, and because it may enable those youth with pronounced mechanical instincts to find and develop their peculiar talents. And all will agree that the girls in all public primary and secondary schools in country and city should study home economics. 
The expense of developing strong agricultural courses in city public schools is prohibitive, because even with state and federal aid few cities would be able to support courses for all the rocations in their own districts. Agricultural secondary schools, consolidated rural schools, and the small district rural schools, for a similar reason, cannot offer courses in mechanic arts, commercial business, and other city vocations. Large highly differentiated schools covering all fields might be devised, but they would not be near the people where the pupils can sleep in their parents' homes.

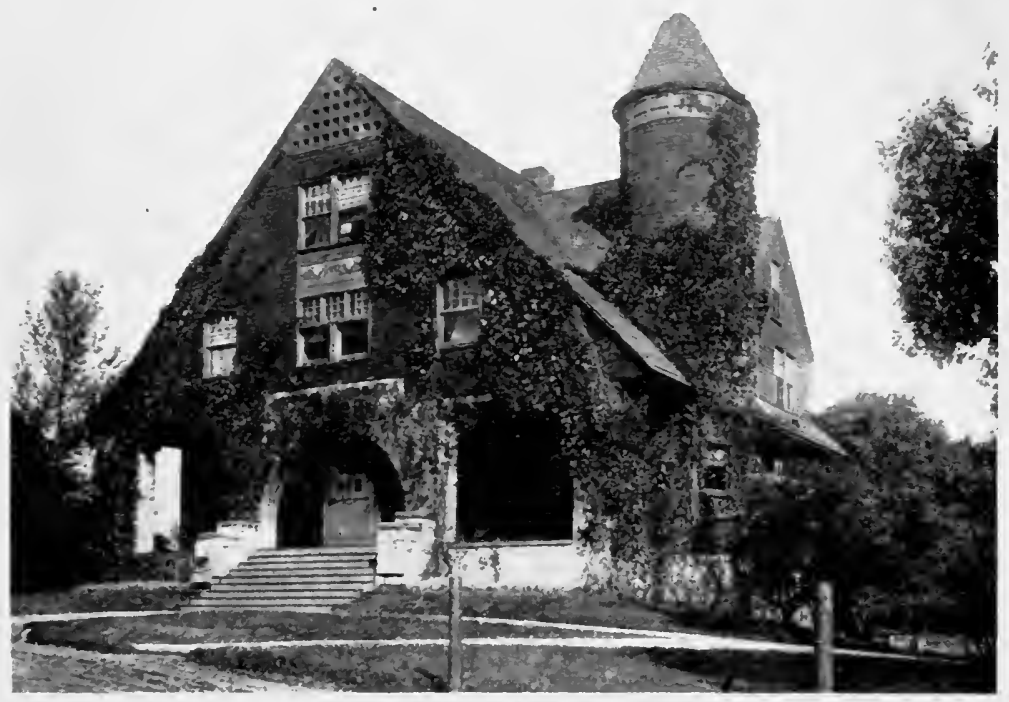

Fig. 1.-First building of Minnesota's first secondary Agricultural School-on University Farm, St. Anıhony Park, St. Paul.

For those who cannot secure in their home schools vocational training along the lines they desire, special vocational schools are necessary. For the non-agricultural industries these schools may best be located in large centers of population, so far as practicalle, in the atmosphere of the rocation for which preparation is sought, and near the homes of a large portion of the pupils, each choosing that school which best meets his needs. For the agricultural industries these vocational schools should be in the country; preferably near a town or city. Those experienced in agricultural secondary schools designed mainly for young men and young women who are to remain on the farm, or are to change from city to country life, are unanimous in the belief, so far as I know, that these schools will not succeed so well as annexes to city schools as when separate and on large farms. As the school of art, theology, literature, or science needs an environment, an atmosphere of its 
own, made possible by a strong special group of teachers and students in a large institution, or in a separate institution, so the finishing industrial vocational school secures advantages from being distinctive as a separate school or as a strong unit in a large school. Weak industrial departments in schools mainly devoted to non-industrial subjects, are being developed pedagogically, and as the industries become better organized so as to increase the amount and regularity of employment, these industrial departments will oftener than now succeed, whatever the school environment. But it will always be true that the schools highly developed for special work in agriculture, in the mechanic industries, arts, and trades, and in home economics, will establish

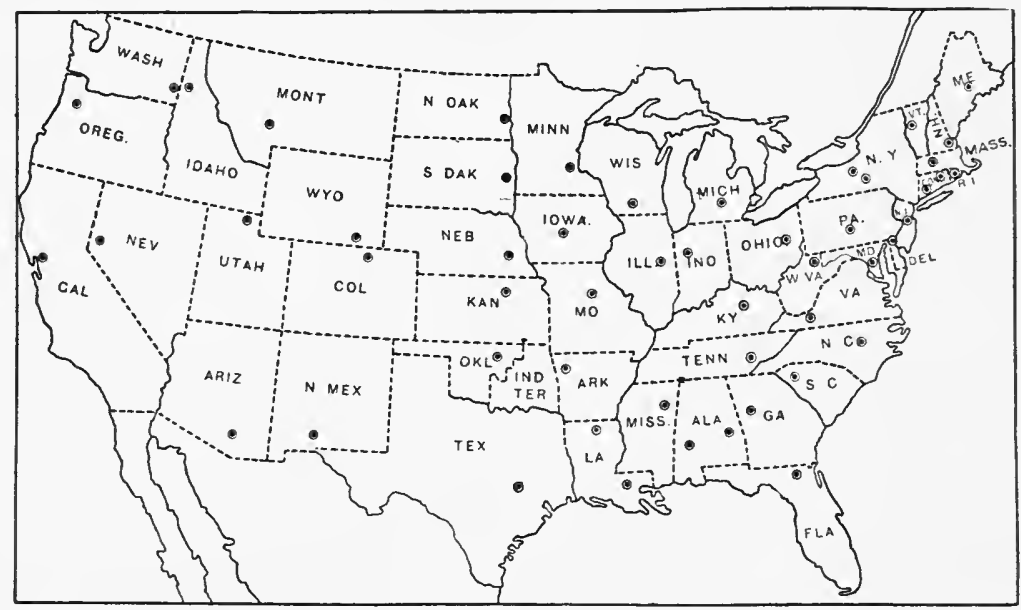

FIG. 2.- Location of the State Colleges of Agriculture and Mechanic Arts wiin their State Agricultural Experiment Stations.

the highest standards in education in these respective lines. The trend seems strongly to the development of large secondary mechanic-arts schools and large secondary agricultural schools as parts of our public-school system, and to include home economics in both. There are, however, none so narrow as to limit instruction in these practical lines to these large special secondary schools. The industrial studies are finding more and more room in the academic public secondary schools in cities; and especially in the secondary schools of villages, towns and cities not large enough to support separate technical schools. Even short trades courses are finding favor in the public schools of some smaller towns where there is need for expert tradesmen in specific industries, as well as in large centers of population. And even the primary schools of our cities are giving more and more attention to mechanical and home-making vocational work.

A most powerful movement has set in to place agriculture and home economics in our rural schools. The efforts have been fairly fruitful in 
devising ways of successfully installing at least the beginnings of these studies in the one-room district school. But modern conditions have decreed that the little red schoolhouse shall live in blessed memory, and that gradually the consolidated rural school shall take its place, and shall grandly combine the general and the rural rocational subjects into a broader, richer, and more useful course of study. Here is the most promising of all fields for vocational school work in relation to the productive industries and to the homes of the community.

It is worthy of note that there are already established, or being established, thirty agricultural secondary public schools out of the 300 needed to place

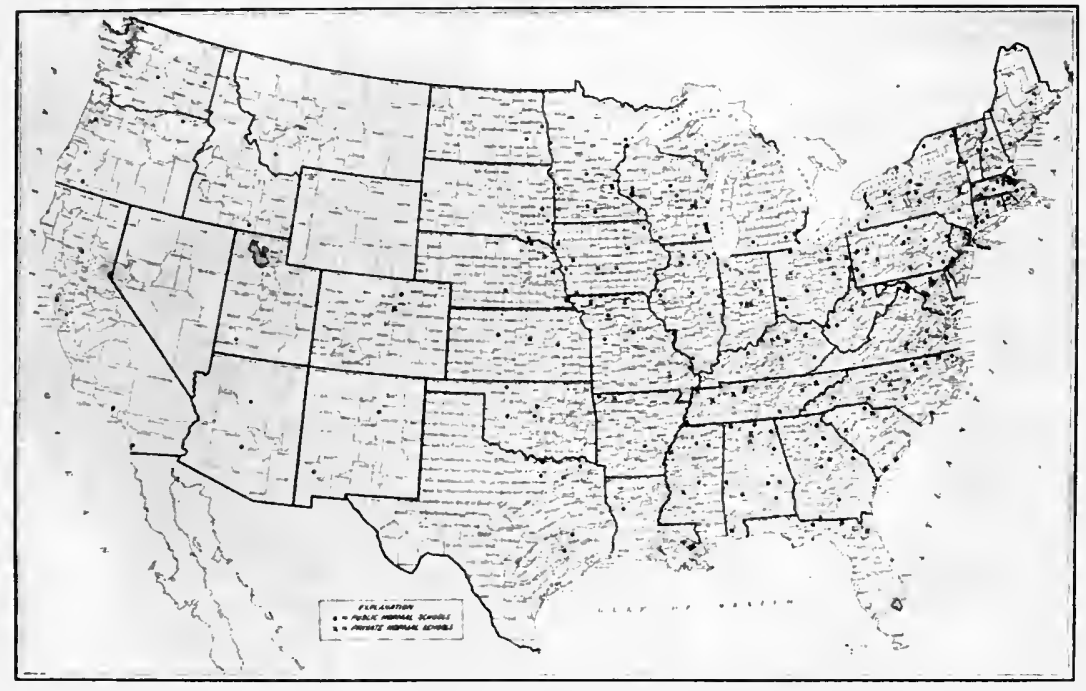

Fig. 3.--Location of State Normal Schools shown by dots and Non-public Normal Schools shown by crosses.

one in each group of ten of our 3,000 agricultural counties. Even more significant is the fact that 600 consolidated rural schools have taken the place of 4,000 little district schools and that two-thirds of our district rural schools seem destined eventually to give way to the consolidated rural school. It seems clear that the great bulk of all instruction in agriculture and country home-making will be given in the consolidated rural school. The argicultural secondary school will set standards for the consolidated rural school and provide its teachers, and the graduates returning will make possible its excellence. The colleges of agriculture, the state experiment station, and the federal and state departments of agriculture will each serve most important purposes; but they will do their largest work thru the consolidated rural school. In this neighborhood school two-thirds of the farm boys and girls will combine school-going and apprenticeship education on the home farm. 
In the districts too sparsely settled or too isolated to consolidate their schools, the other one-third of our rural youth will have teachers who have been trained in the consolidated rural schools, in the agricultural secondary schools, and in the state normal schools equipped to prepare teachers to instruct in farming and home-making.

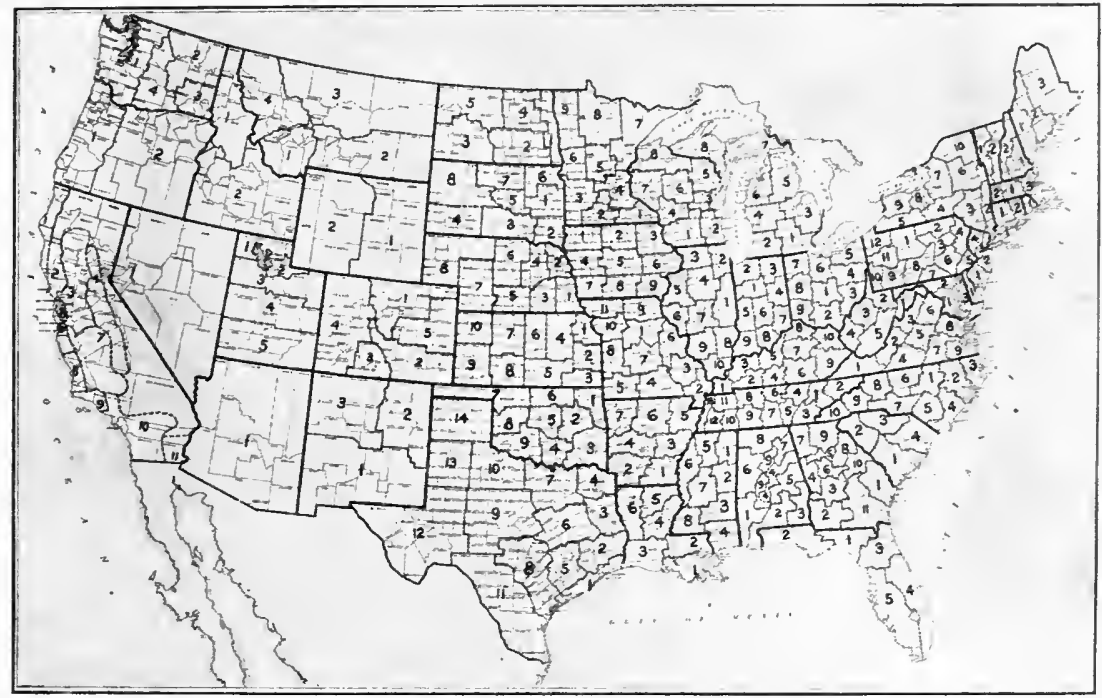

FIG. 4--Suggested plan of districting each state for combined Agricultural HighSchool and Branch Experiment Station districts. Colored districts are not shown. This first draft, made with help of residents of respective states who know soil areas, cities, and their transportation facilities, and other controlling conditions, can be much improved upon, as by committees of the respective state legislatures or by state boards to whom the legislatures might delegate the districting as well as the locating of the farms and institutions within the districts. The figures are designed to be near where the schools would be located, if this plan of districting is followed in the state.

\section{AN ARTICULATED SCHOOL SISTEM}

The United States has a system of articulated schools for non-agricultural communities well organized. The primary eight-grade schools, including simple forms of instruction in manual training and home economics, are now well defined in most states. The secondary four-year courses in academic studies, often with electives in technical and industrial lines, in technological subjects, trades, business and home economics, and the shorter vocational courses, as in trades, business, and home economics, are also being definitely organized. The same is true of the collegiate schools offering academic courses, often with many elective subjects leading toward rocations; professional courses, as law, medicine, and pedagogy; science courses, as chemistry and physics, and engineering courses, as electrical and mechanical. 


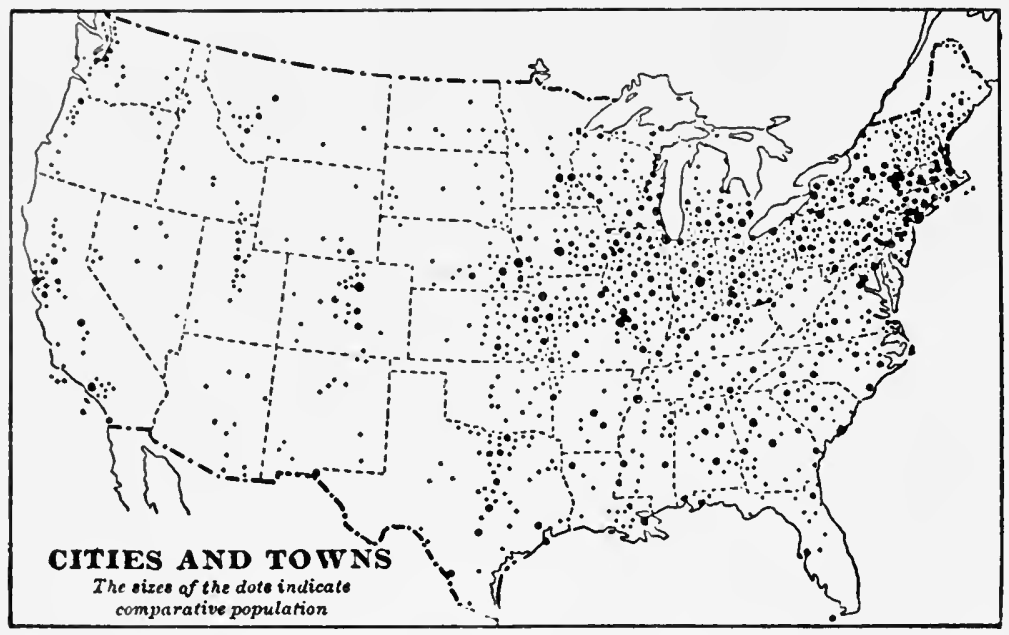

FIG. 5.-Roughly showing location and relative size of cities in the United States. Under the proposed law, these cities would receive from the federal government, for education in the mechanic arts and home economics, one-tenth as many dollars as they have inhabitants.

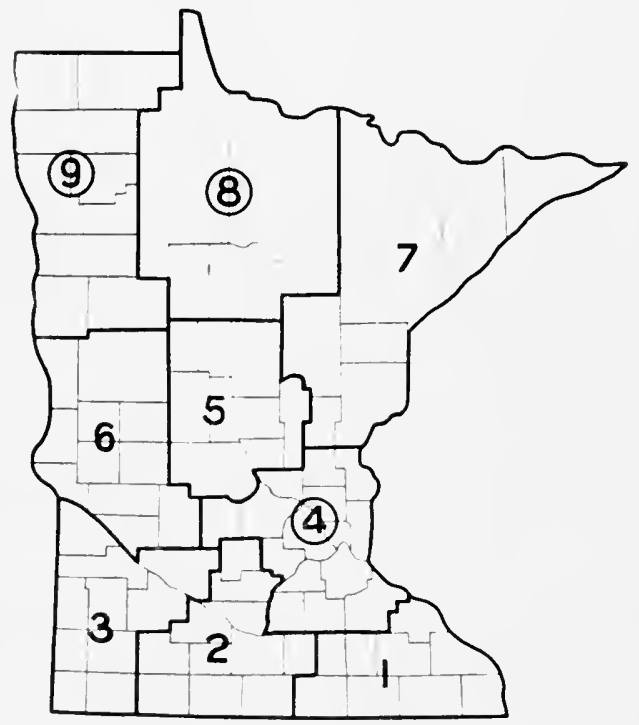

FIG. 6.- Showing a proposed plan of dividing Minnesota into nine agricultural highschool and branch-station districts. The original agricultural high school as located in District No. 4, along with the agricultural collegiate course and the State Experiment Station or "Central Station" on University Farm. In District No. 9 are the Red River Valley, or Crookston, Agricultural High School and branch station. In District No. 8 a branch station only was establisherd in 1896 . 
For agricultural communities the one-room rural district school with six to eight grades, including wherever practicable some agriculture and home economics, is the well-defined type; and no doubt it will remain in one-third of our agricultural area. The consolidated rural school with eight primary grades, and two secondary-school grades including instruction in agriculture and home economics, is coming forward as a type of local school for all of our more productive agricultural areas. In some cases, this school is combined with the village school, but in most cases it is in the open country with only farm patrons. Estimates place the number of strictly rural con-

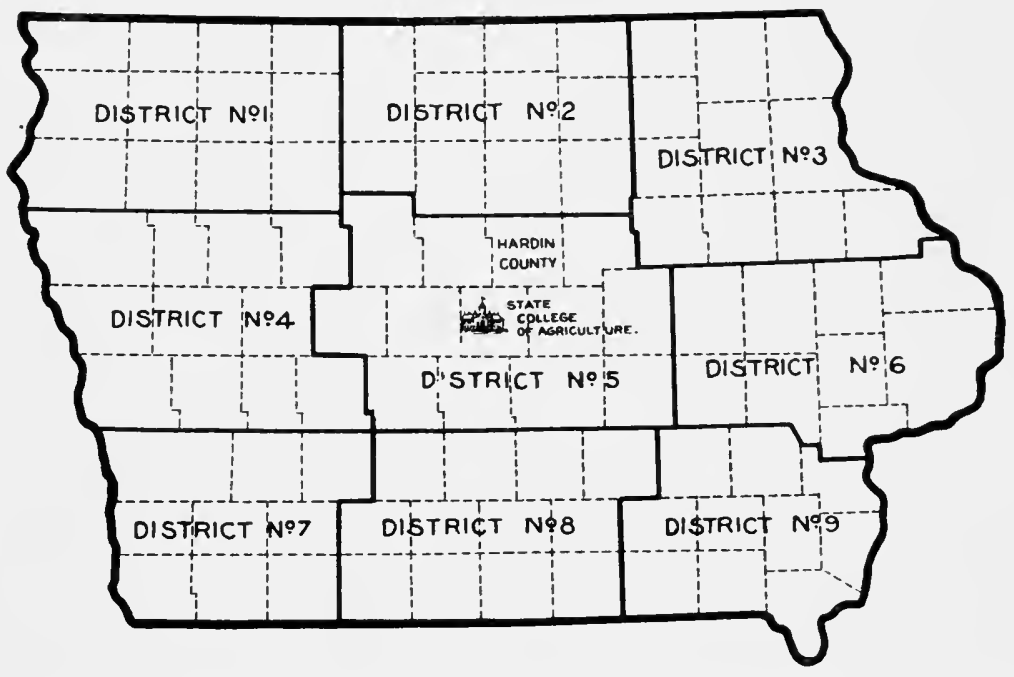

FIG. 7.-Plan for nine combined agricultural high-school and branch-station districts for Iowa. The State College of Agriculture and Mechanic Arts is shown at Ames in the middle of the central district. Hardin County (shown in detail in Figs. $\mathbf{I}_{2}$ and $\mathbf{I}_{3}$ ) is shown just north of the center of the state.

solidated schools, each covering an area approximately 5 miles square, at 600 . This type of school is far more advanced in type, in numbers, and in the firm hold it has taken on the rural community, than is realized by any but the few who have especially studied this class of schools. Mr. George W. Knorr, after visiting 200 consolidated rural schools, estimates that more than 99 per cent. of their farmer patrons have become ardent supporters of consolidation. The farmers who try this form of school are as unanimously in faror of it as those who adopted the grain reaper or the sewing machine upon first trial were in favor of those implements.

The secondary agricultural school with the third and fourth high-school grades or years is coming forward to supplement the two high-school years of the consolidated rural or village school; and the little unconsolidated school with four-year secondary courses in agriculture and home economics. 
Every person, so far as I know, who has really absorbed the plan and spirit of agricultural secondary schools as developed in this country, and especially those who have followed the farm boys and girls thru these

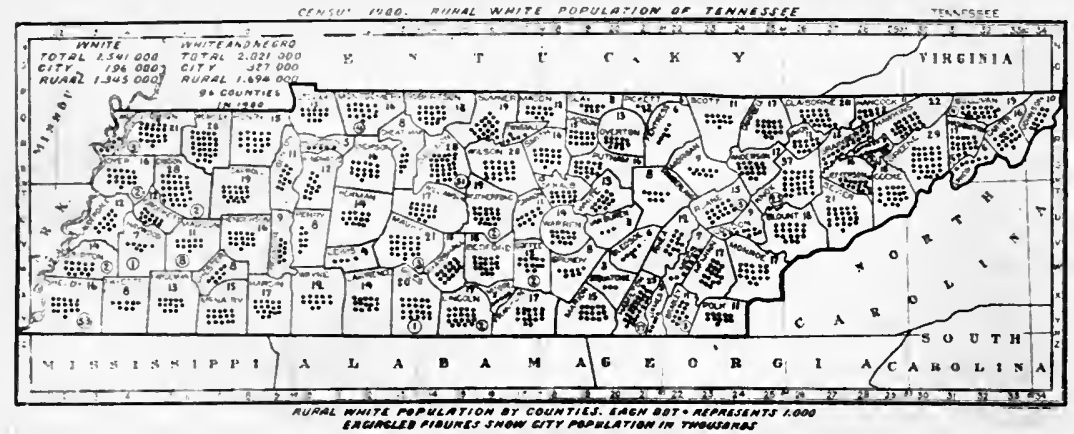

FIG. 8.-Showing distribution of white rural population of Tennessee. Each dot in the respective counties represents 1,000 people on tarms and in towns of less than 2,500 . Figures in circles represent thousands of people in cities with over 2,500 population.

schools back to the home farm or into the college of agriculture, is exceedingly optimistic concerning the future relation of this class of schools to our country life.

The college of agriculture thru half a century of struggle has gained an honorable place among collegiate institutions, and these institutions already

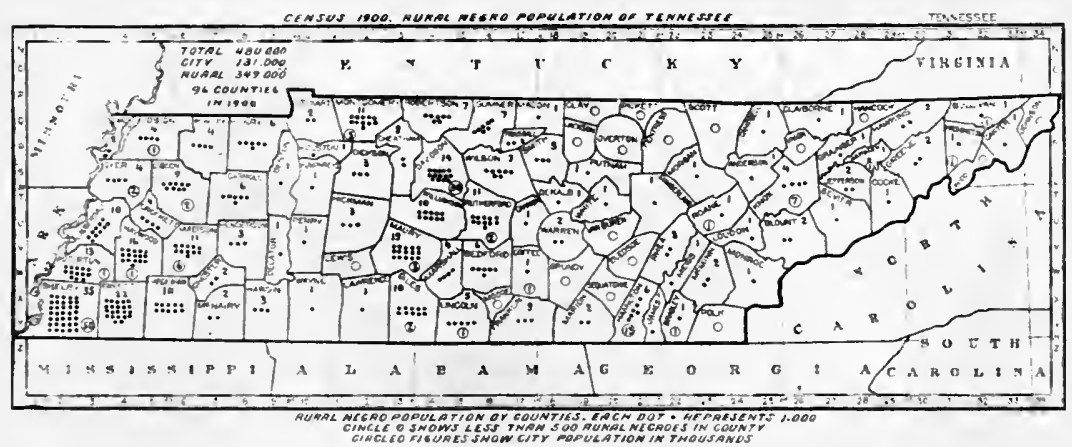

FIc. 9.- Showing distribution of rural negro population of Tennessee. Each dot represents $\mathrm{r}, 000$.

form a crown to that branch of our system of articulated schools which is related to our country life. Buttressed by the research work of state agricultural experiment stations and departments of agriculture, the improvement of the quality of work in these institutions is going forward rapidly, and the multiplication of agricultural research and educational institutions is greatly increasing the demand for their graduates. 
There is keenly felt in our agricultural education a need of such an articulation between the schools relating to agriculture and to country life as exists between all our schools and the colleges devoted to the non-agricultural professions. The farm youth has no continuous school ladder in the line of his

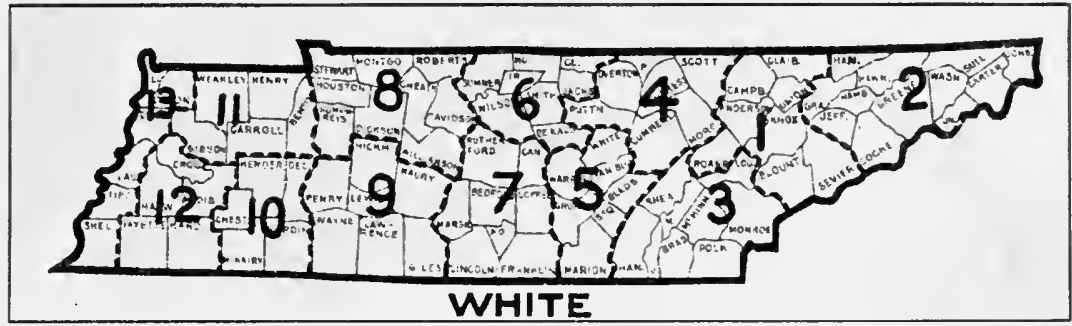

FIG. Io.-Suggested plan of dividing Tennessee into agricultural high-school and branch-station districts for whites. The person suggesting this plan made the districts smaller than did most of those suggesting plans for other states (see the states in Fig. 4).

early training, and few are encouraged to go on to our poorly filled collegiate agricultural courses. Some secondary schools are needed which along with a broad training lead farm boys forward to leadership in technical agriculture as well as into other vocations. But what is still more needed is broad secondary courses which articulate at both ends with the farm; which attract those

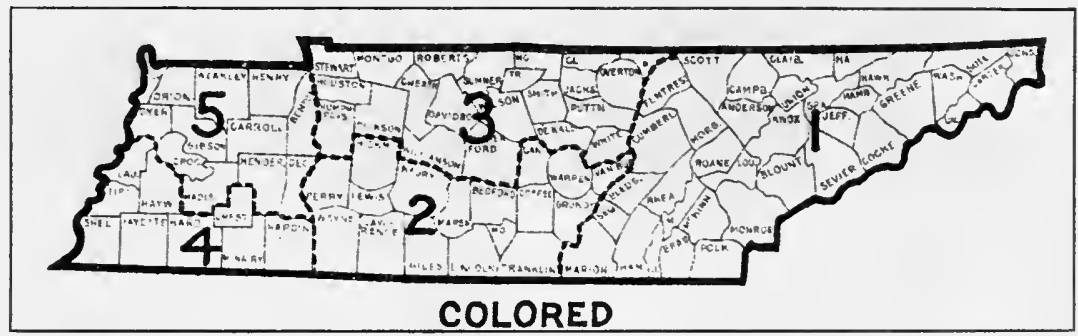

FIG. II.-Suggested plan of districting Tennessee for the colored secondary agricultural schools. Owing to the smaller number of negroes, not so many districts are provided as for whites, as shown in Fig. I0. Since the denser areas of colored population are in different parts of the state from the denser areas of white population, the districts are in no way coterminous, each located to suit the needs of the race.

farm youths who are to remain on the farm and specifically prepare them for their work.

Those who fear that providing special schools which would graduate annually 20,000 to 30,000 farm boys and girls in secondary agricultural schools would divide our school system into two systems need only to use arithmetic to discover how small a part these are of the three millions who annually close 
their school careers. The problem will still remain of reaching the several million pupils from rural homes. The establishment of several hundred strong secondary schools of agriculture, and of mechanic arts, as well as the introduction of agriculture, mechanic arts, and home economics into our public normal schools, will make possible the introduction of these subjects into all our schools. The opportunity which seems to offer of installing vocational education thruout our school system seems a very large interest compared

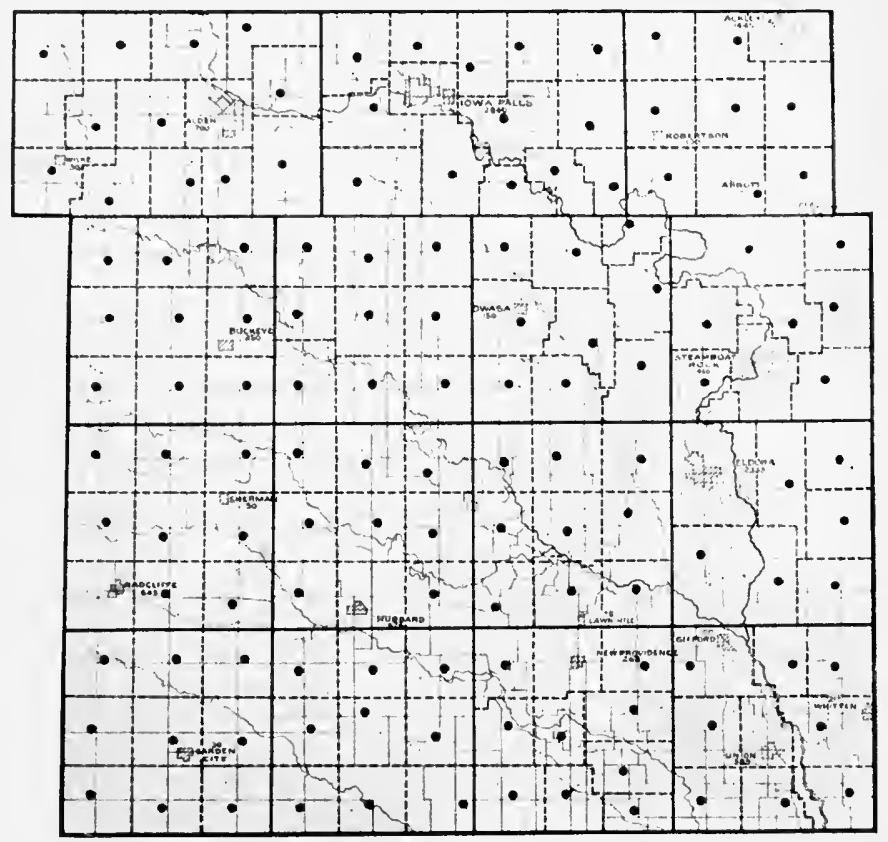

FIg. I2.- Showing the ${ }^{1} 32$ one-room rural schools in Hardin County, Iowa. This county is near the center of the state (see Fig. 7). Beside 1 he 132 district rural schools there is a number of "independent" districts including with a town or village a portion of the surrounding country.

with which mere local interests are of very minor weight. Those interested in our youth will be able to make our schools even more American than they now are if the American industries have a larger recognition in all classes of our public schools.

The connection of our collegiate, secondary, and elementary schools which deal with country life with our state experiment stations, with the U. S. Department of Agriculture, and with other institutions which discover new truths, creates new values as by breeding plants and animals, and helps devise new pedagogical methods in technical studies, on the one hand; and their connection, on the other hand, with the practical management of our farms and farm 
homes, is of far greater significance than any relations between city and country life schools, important as they may be. The unity with the home education during school life and with the after-graduation life-education is the matter of larger concern. The few finding it well to do so can easily shift from non-agricultural to agricultural courses, or the converse, with far less loss to society than will occur from having the schools lead many into fields other than those into which the pupils are to go. The schools which

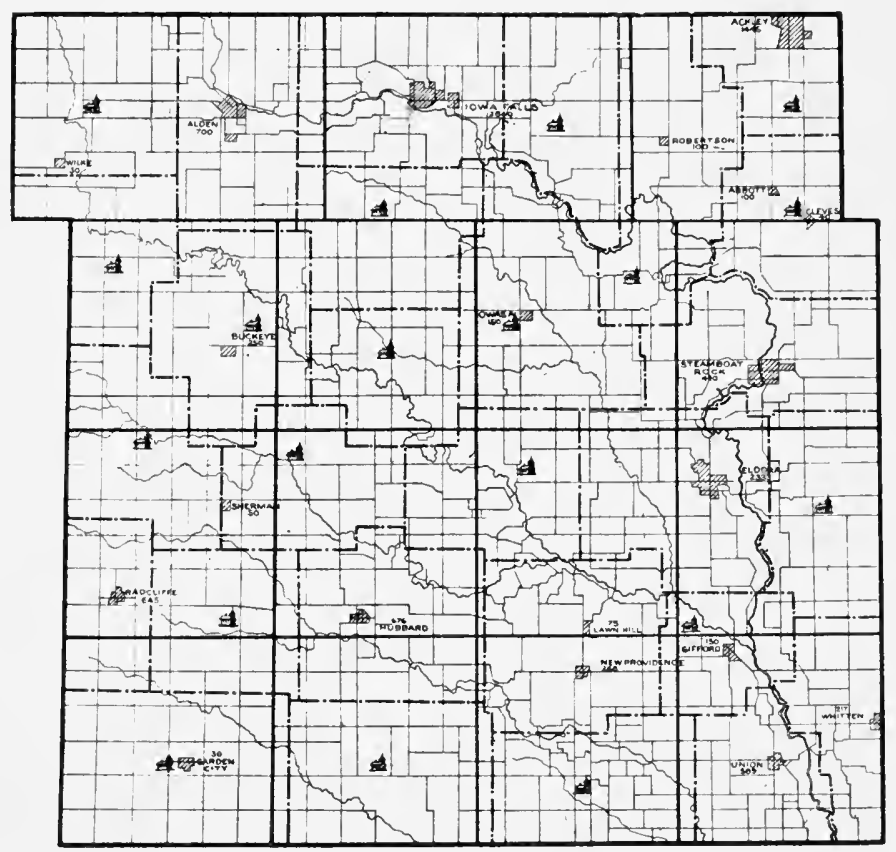

FIG. I3.- Showing a plan for redistricting Hardin County, Iowa, for consolidated rural schools. About 20 consolidated rural schools will replace the I 32 one-room schools. The plan contemplates districts about 5 miles square, and that teams paid for by public funds shall haul the pupils to and from the schools. More pupils will be hauled to the village schools than now. In the few instances where practicable, trains and trolley lines will be utilized instead of teams. Grant Farm School District (for which a plan is shown in detail in Figs. $\mathrm{I}_{4}$ and $\mathrm{I}_{5}$ ) is on the southern boundary of the county, just east of Garden City.

today, are dwarfed as compared with the functions they have to perform, are those secondary schools or "peoples colleges" which lead to the industrial vocations where large numbers are to be accommodated.

It should clearly be recognized that the types of primary, secondary, collegiate, and graduate schools to make a well-formed American educational system are all present, and that the weakness of the system is quantitative. The secondary academic schools leading to the collegiate and graduate professional and so-called higher technical vocations are not outgrown; the 
schools leading to the productive industries are simply undereloped. To articulate with the farm, the shop, and the home in a broader and more unified

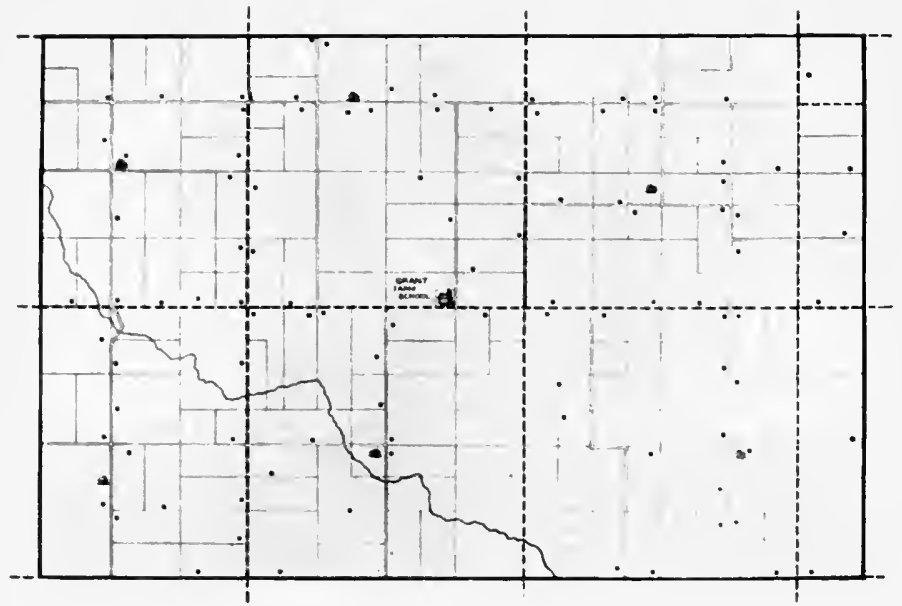

FIG. I4.- Showing the consolidated farm school in the center of Grant District, one of the proposed consolidated districts in the southern part of Hardin County (see Fig. 1.3). Six one-room district schools which are to be abandoned are shown. The locations of the Ioo farm homes are shown.

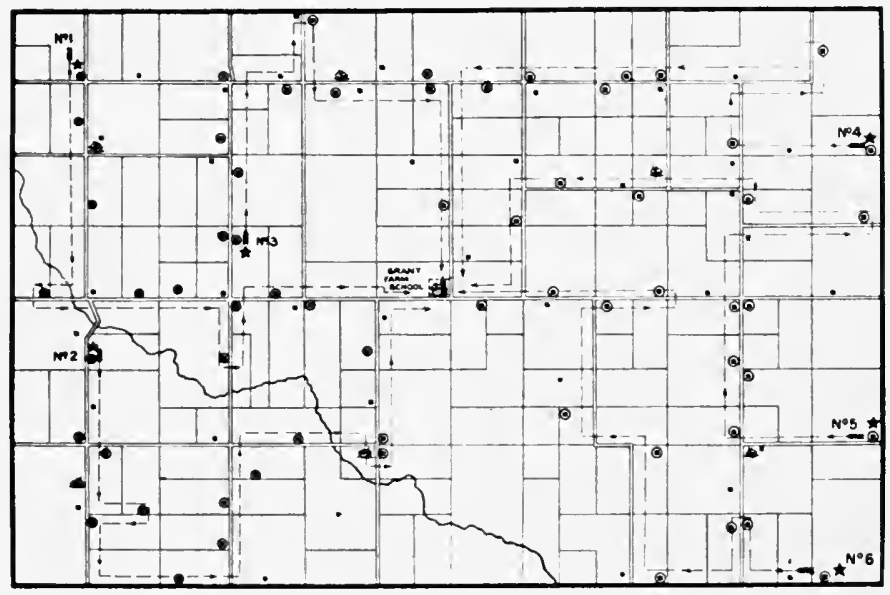

FIG. I5.-Grant District, showing the proposed consolidated rural school, the six schoolhouses which will be abandoned, and the wagon routes between the homes and the new farm school. The stars show the proposed starting-places of the 6 school wagons and the dots wilhin circles show those homes from which children are going to school this year.

way the rocational studies must be magnified. While all our schools need strengthening, placing equal stress on building up all classes of schools on their present status would retain the present unequal development. The 
need of the hour is to build up the industrial vocational courses in our system of secondary schools.

Some conservative persons have wrongly defined the vocational school as an institution in which industrial subjects displace the accepted academic studies. The fact is that most of these courses are approximately one-third academic or literary, one-third scientific, and one-third vocational. Practically, the foreign languages and a small part of the other general studies give way to book, laboratory, and shop or outdoor studies related to the basic industries of the community or to home-making. In two ways these courses

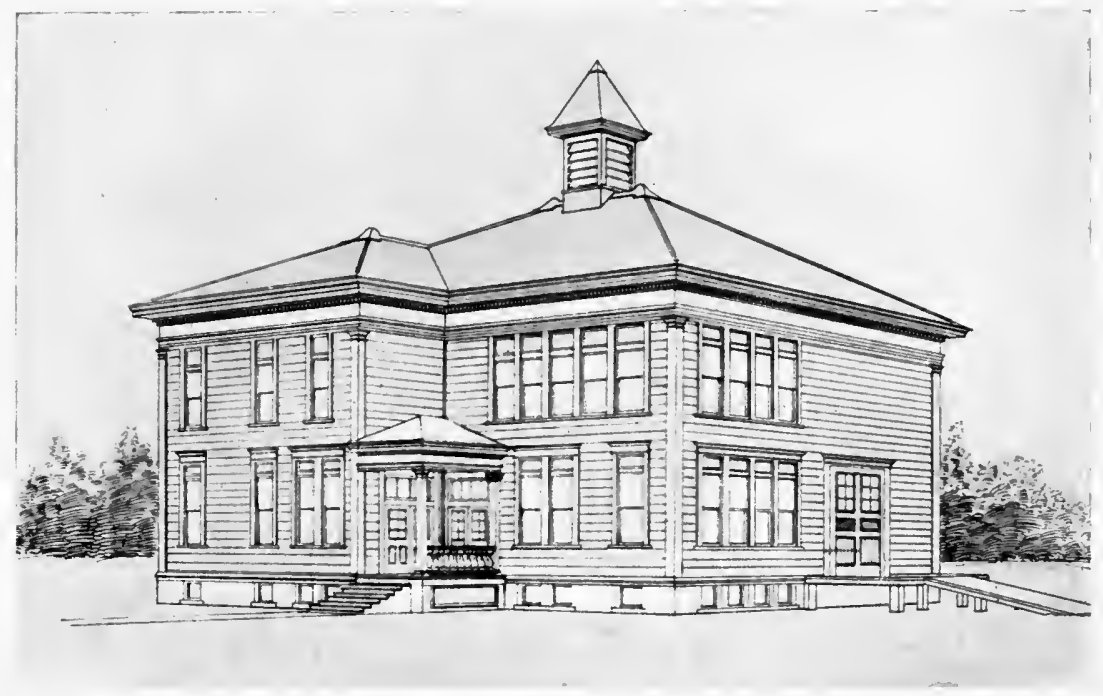

FIG. I6.-Perspective view of building proposed for Grant Farm School.

are broader than the general academic course. The student can accomplish more when part of his work is with things, and his book work is brighter and means more to him. His other studies have a clearer setting, a keener interest, and wider co-ordinations. The more practical school leads to a broader view of life, better fitting the youth to choose a calling. It at once prevents the dreamy student from becoming bookish and holds the too practical student longer on his book tasks.

One prominent educator has expressed fear that to supplement our school system with secondary schools highly equipped for training in farming and farm home-making would peasantize our farmers. Suppose the great state of Iowa had ro of these schools with a total of 5,000 students, and should graduate annually I,000; suppose further that 400 of these graduates would become teachers of agriculture and home economics in consolidated farm and village schools, eventually for the most part becoming farmers or farmers' 


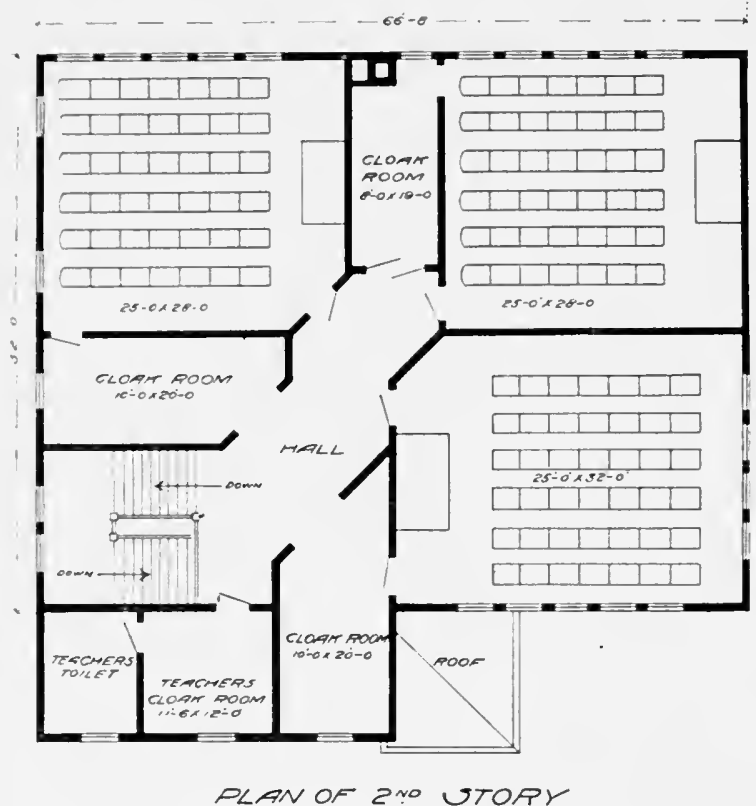

FIG. 17---Upper-floor plan of Grant Farm School building. Three recitation rooms for pupils in the eight primary grades; with a cloakroom for each schoolroom.

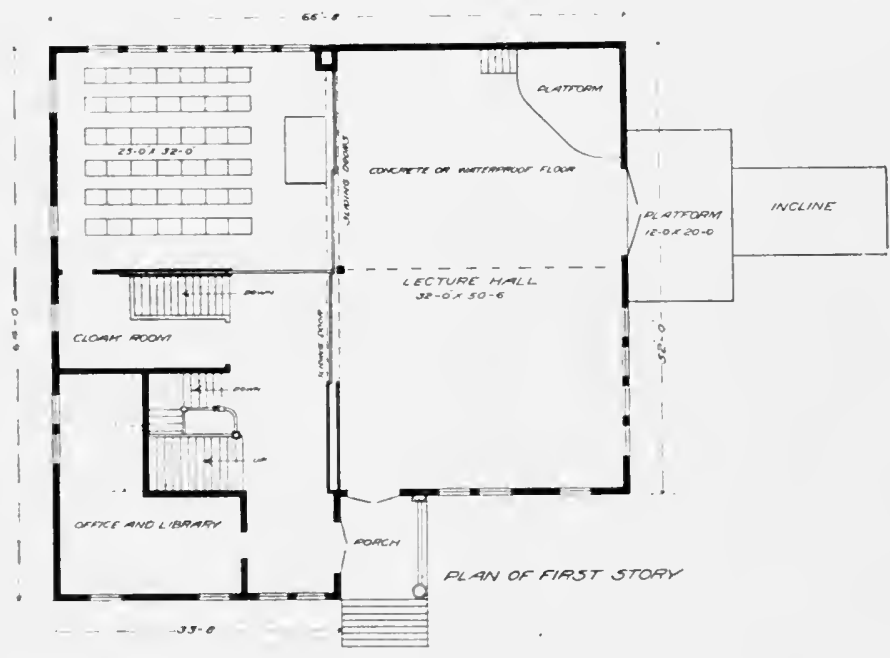

FIG. IS.-Ground-floor plan of Grant Farm School building. One recitation room and a large laboratory room for the first-year and sccond-year high-school classes. The lahoratory may be used alternately for agriculture and home economics. Sliding doors allow the entire lower floor to be made into an audience room facing the stage in one corner of the laboratory, that school meetings and public meetings may be accommodated. This room will be as useful in preparing pupils to express their ideas as in working with their eyes and hands. 
wives; 400 return to the farm direct; 100 go forward to the agricultural college, and roo into non-agricultural vocations. How less than one trained farmer per township would peasantize the farmers of a state is not made clear. It may be supposed that the author of that statement conceived the idea that the oncoming consolidated rural school and the agricultural secondary school would be narrowly agricultural.

Those who are experienced in developing secondary courses in both of these classes of schools for the vigorous American farm boy and girl realize

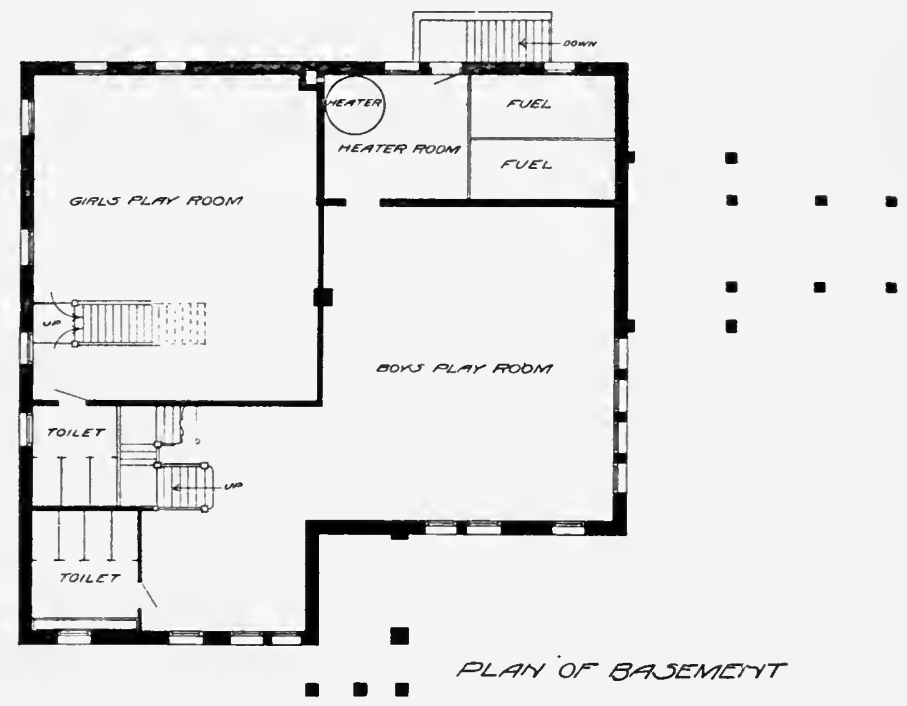

FIG. I9.-Basement plan with playrooms for inclement weather. Boys and girls have separate entrances. This can be left out of the plan in mild climates and where economy is necessary. Where economy or difficulties of drainage make it necessary, the waterclosets may be in separate buildings.

that the course of study is broadened by adding to nearly all the academic work ordinarily giren in high schools strong, inspiring, practical subjects relating to the farm and the farm home. Since the mind is here developed along lines in which it is to have food for thought thruout life, the education is truly started for the whole lifetime.

How so changing our courses of study in the rural schools that the youth not only receives rocational training but remains longer in school and secures more of the traditional education as well, will peasantize farmers, has not been shown. It certainly is not based upon intimate knowledge of the actual effects of typical schools now in operation. That education can un-Americanize or peasantize, is truly a novel proposition.

Money can never secure the land from farmers highly trained to succeed in and to appreciate the management of farms and farm homes. Strong 
schools combining general and rocational education are the nation's great safeguard against peasantizing the people. Educated people rule. Our fathers installed Americanism on this rich continent, and thru a broad and efficient educational system the kings of finance are to be kept under the rulership of the people. Newly centralized commercial powers require newly

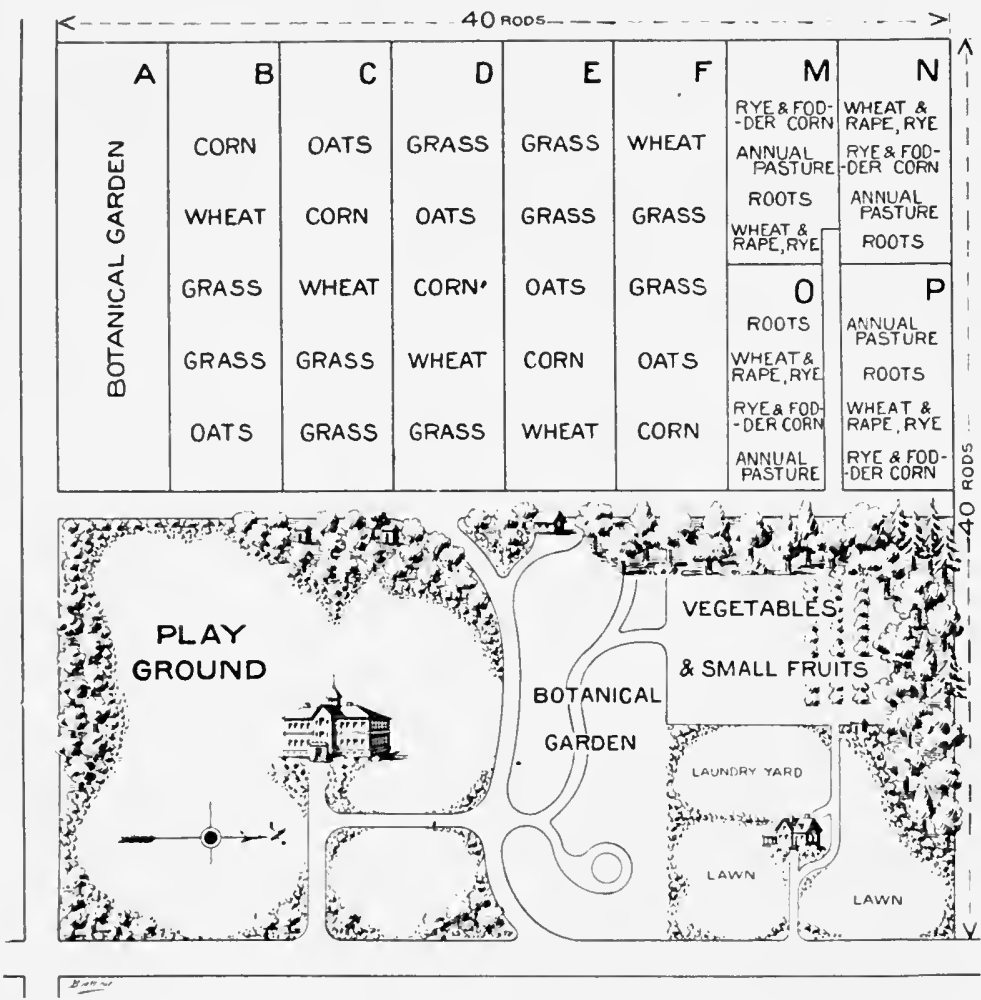

Fig. 20.- Plan of consolidated school farm. Five acres are devoted to combined farmstead and campus, with forest, ornamental and fruit trees and shrubs, garden vegetables, and flowers, and ample playgrounds. Besides the school building a cottage for the principal and small farm buildings are shown. Five acres are laid out for experiment, demonstration, and praclice insiruction and field crops, farm management, the use of fertilizers, and the cullivalion of the soil.

organized power of the people. The productive unit-the man-must be increased in economic, social, and political power, and this requires general and rocational education.

The same author objects to building up schools especially deroted to country life, fearing that the village and city schools will be seriously injured by withdrawing from them the vigorous farm boys and girls who now attend there. Another writer insists that our republicanism depends upon educating 
all classes together in one set of schools. The experience of 600 consolidated rural schools has shown their 10,000 farm patrons that this and many other objections to country life educational institutions are fallacious. In so far as experiments have gone in the mapping of counties to consolidate our rural schools, the tendency has been for more rather than less pupils to be conveyed into the schools of villages and smaller town centers. The method of dividing the districts so as to carry more to the village school, thus helping to build it

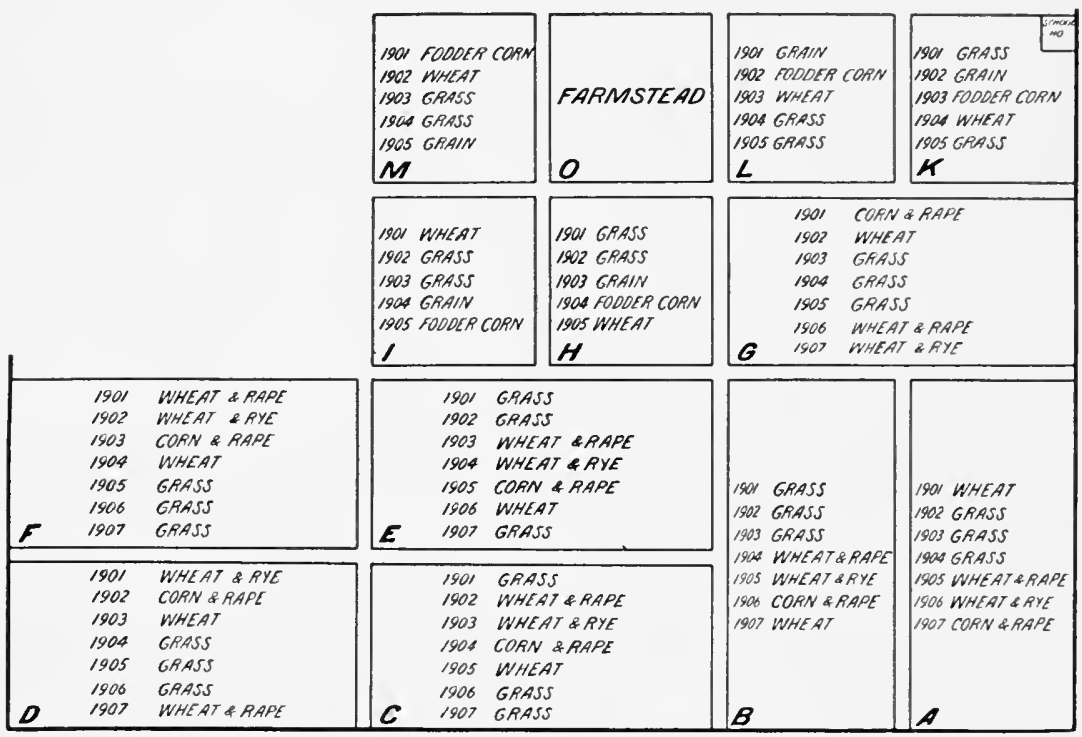

FIG. 21.-Plan of Spring Lawn Farm, Morris, Minn. This farm was placed in miniature on the grounds of the little rural school on its northeast corner, with fields only 6 to $\mathbf{2}$ feet across. A dozen such miniatures of the best farms of the consolidated farm-school district can be placed on the consolidated school farm. Each farm will need an area of only 4 to ro square rods. The older pupils can do the work on their weekly day at school during summer, thus coming in contact with many of the same practical questions in farm management which the owners of the actual farms must meet at the same time.

up, or to carry more to the consolidated farm school more or less distant from the village so as to better insure a rural atmosphere, is a subject as yet open for investigation. Where there is a village as well as a rural community to be served, probably combining the village school and the school for the rural pupils on a school farm beside the village will oftenest best serve the largest number. But the farm school out in the country, and the agricultural secondary school, where the farm boy or girl at the age of 17 to 20 boards for two or more winters, will give a vastly broader point of view, a wider acquaintanceship and a stronger social status as well as a better preparation for the management of the farm and the farm home than is possible under the alternative plan of 
a little agriculture in a general course of study or of a little agriculture and home economics in existing schools.

Allowing agricultural education just to grow, or trying the impossible task of securing state money to introduce agriculture into existing secondary schools, nearly all of which are in cities, is apparently a very poor alternative.

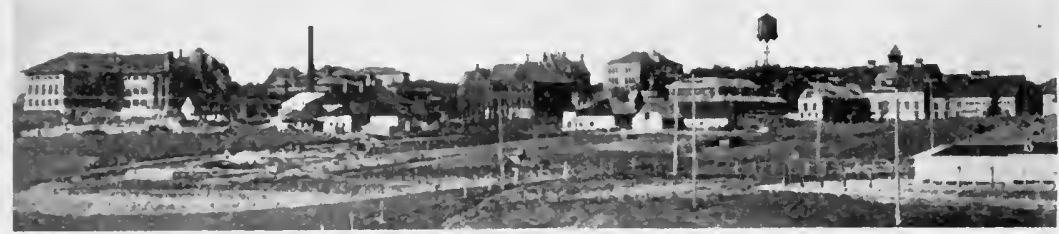

Fic. 22.- Present campus of the oldest and largest American secondary agricultural school on University Farm, St. Anthony Park, Minnesota. The State Experiment Station and the agricultural classes of the collegiate agricultural course, also the dairy course and the "short" or "farmer's" course are also accommodated in these buildings.

Let that education for rural youth grow as it will, but let us give specific direction to federal and state money into vocational schools to set standards for and impetus to a more practical education in all schools. All know that local tax measures of the state or city will do well to yield sufficient revenues for the academic studies. Federal and state money limited to the studies deemed too expensive by the local community, will result in a co-operation

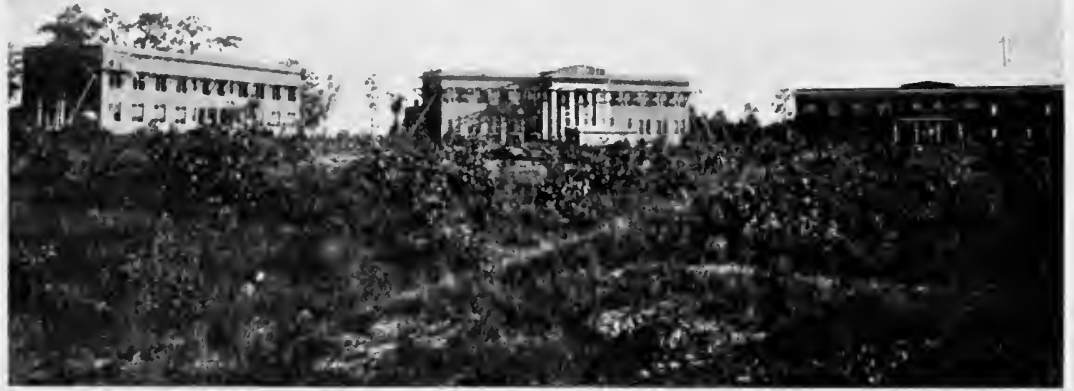

FIG. 23.-Beginnings of buildings for one of Georgia's I I new agricultural secondary schools. The Georgia legislature in July, I906, authorized the governor in co-operation with the people of the respective congressional districts to establish i I agricultural high schools. The state allotted to each of these schools for current expense $\$ 6,000$ from the "tag tax" on fertilizers, and required the districts to provide farms of at least 200 acres each and to equip them with suitable buildings. In eight months by private subscription the eleven districts hacl raised over $\$ 800,000$ for this purpose, thus demonstrating that science in farming, and agricultural education have won the American people. 
between state and locality which will provide schools including both general and vocational education.

The proposition in the Industrial School Bill now before the Sixtieth Congress has rapidly grown into wide favor. Many national and state organizations of farmers, of labor leaders, of educators, and of manufacturers have generally either indorsed this bill or have taken such action that their executive boards may properly favor this measure in practically its present form. Congressman Davis says that many members of the House of Representatives

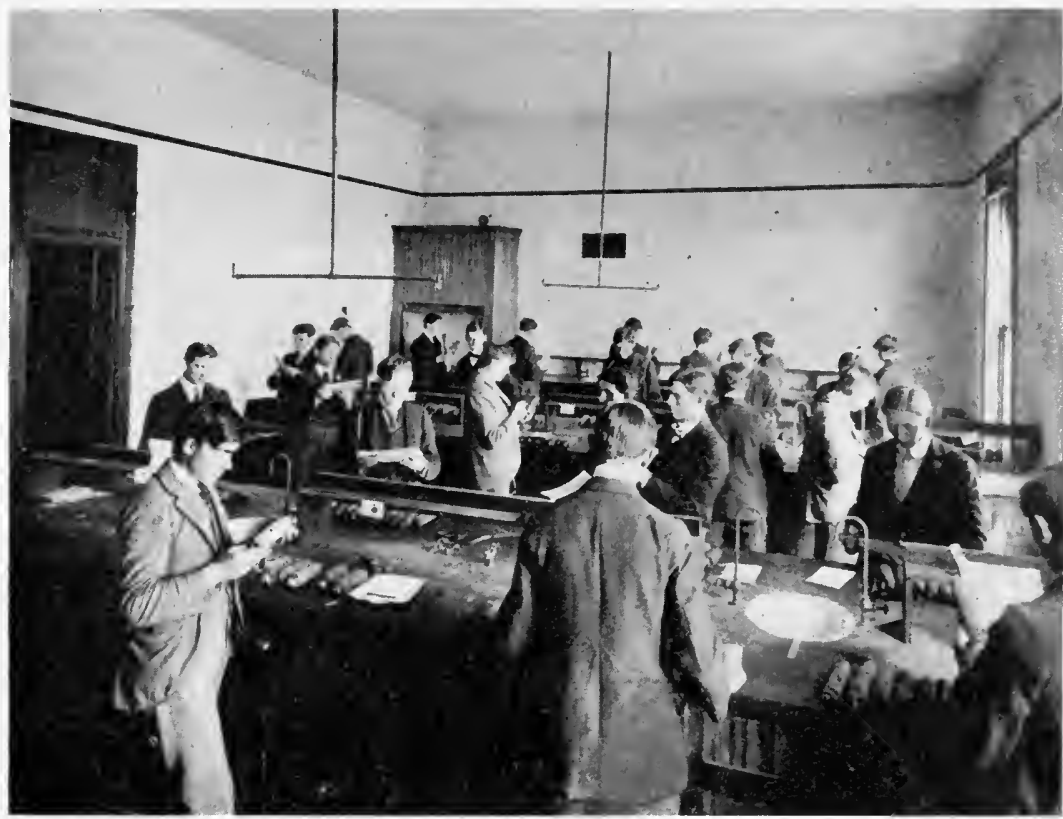

Fig. 24.-Boys judging corn illustrating work, as at an agricultural college, an agricultural high school, a normal school, or a farm school.

and Senate express the desire to help enact it into a law. It equitably distributes money raised by general taxation giving its share to every district in the land. It is generally agreed that the worst fault of our schools is that they discriminate against the productive industries and home-making; and correcting such a general local mistake is clearly a federal function.

Those who earlier feared that national appropriations would tend to centralization realize that taxes raised by the federal government and turned over to the localities with which to build up state institutions accumulate the strength in the state and actually decentralize government. The results from federal appropriations for state colleges of agriculture and mechanic arts and the state agricultural experiment stations absolutely dissipate that fear. Those who feared that the present Secondary Industrial Education 
Bill was the forerunner to revive the movement centered years ago in the so-called "Blair Bill," which designed to put the federal treasury behind our

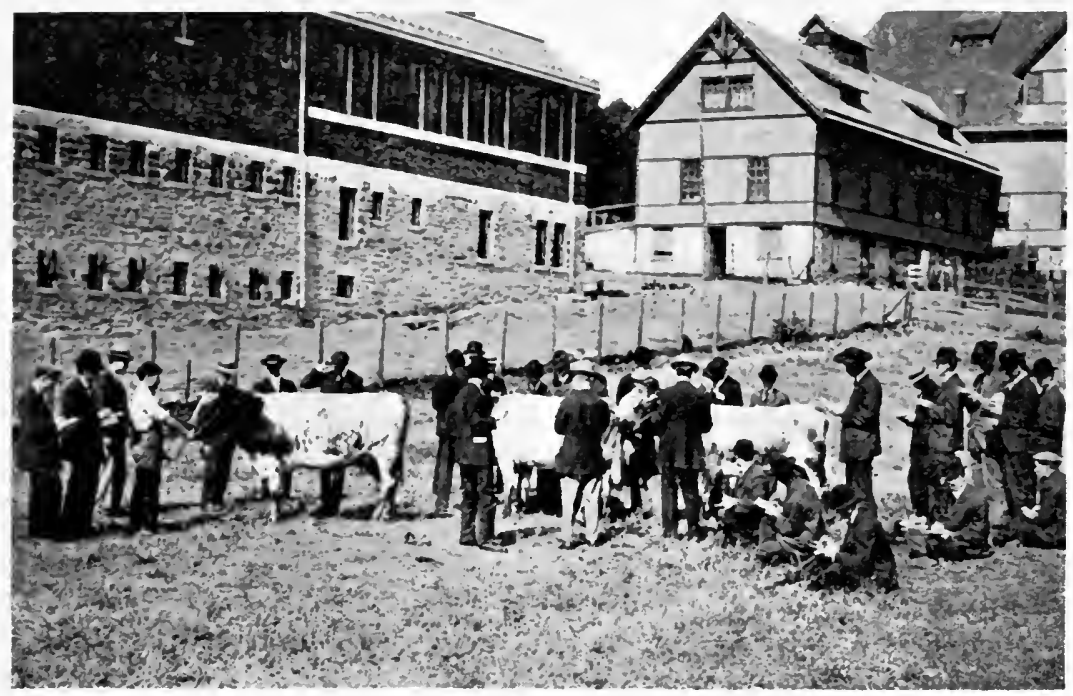

Fig. 25.-Boys studying cattle judging, as jllustrating work at an agricultural college, an agricultural high school, a normal school, or a consolidated farm school.

public-school system, acknowledge that this bill adds no new principle of law to that in the Morrill Act of 1862 , confining the expenditure as it does to industrial education even more rigidly than does that act.

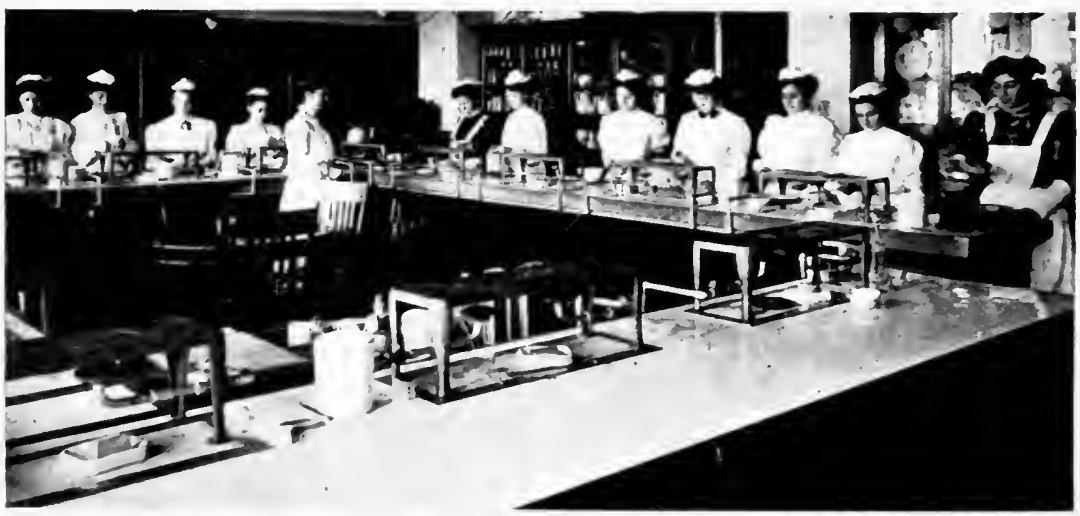

F16. 26.-Girls in cooking-class, as illustrating work at a state college, an agricultural or mechanic-arts school, a normal school, or at a farm school or rural or city primary school. The equipment is usually simpler, lout much of this work can be done in the lower schools. 


\section{INDUSTRIAL EDUCATION IN THE FIFTY-NINTH CONGRESS}

The Fifty-ninth Congress passed the Adams Act adding $\$_{15,000}$ to the similar annual appropriation to each state experiment station; and made into law the Nelson Amendment giving to each state college of agriculture and mechanic arts $\$ 25,000$ more annually. It also liberally increased the research and educational funds of the U. S. Department of Agriculture. But of equal or greater significance is the fact that at this session were introduced bills to extend federal appropriations to secondary education in agri-

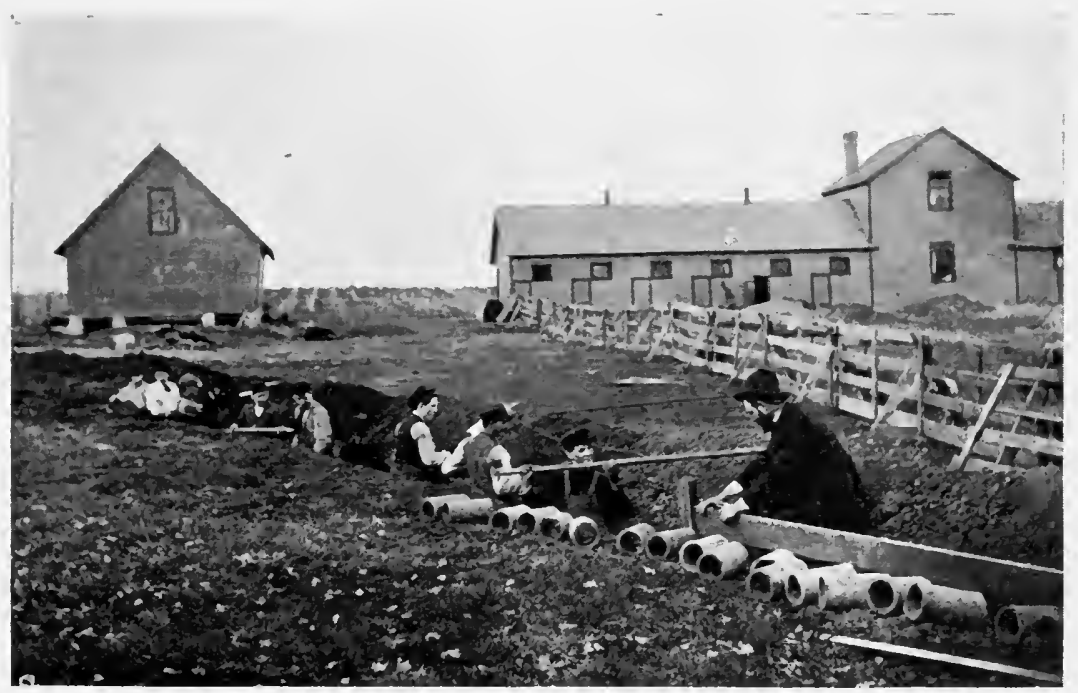

Fig. 27.-Class of boys laying a tile drain, as illustrating work under an instructor on a school farm or on a neighboring farm.

culture and the mechanic arts. Following the meteor-like financing by private subscription which gave $\$ 800,000$ to equip eleven agricultural secondary schools in Georgia, two bills were introduced along this line by members of Congress from that state. One would give \$10,000 to each agricultural secondary school established in a congressional district; the other would provide a fund for a branch experiment station at each of such schools. These were followed by a bill embodying not only these two ideas, but also including funds for mechanic-arts secondary schools in all our cities. A bill to enable state normal schools to prepare teachers to teach industrial work was also introduced.

It is stated of this new bill that it simply carries out the intention of the Congress of 1862 which inaugurated education for the industries by providing for a college of agriculture and the mechanic arts in each state. It seems clear that Congress looked upon all education above the primary school as collegiate education; adranced schools not then having been differentiated 
into secondary and collegiate institutions. Congress had no means of conceiving the magnitude of the undertaking, nor of the resources the present and future decades can afford to devote to this rocational education; and at that time there were only vague dreams of our great Department of Agriculture or of state experiment stations.

Briefly stated, the terms of the proposed bill provide that Congress shall appropriate annually to each state Io cents per capita for secondary industrial



FIG. 28.- Boys at work in a blacksmith shop, as illustrating elementaryinstruction in a mechanic arts college or high school, in a secondary agricultural school, or in a trade school.

education. Of this sum each city with more than 2,000 inhabitants shall receive its per-capita share, the only limitation being that this money shall be used for studies in mechanic arts and home economics in schools of secondary grade. To the population outside of cities of the size named the Io cents per capita shall be used for studies in agriculture and home economics in secondary agricultural schools. In both the city secondary industrial schools and in the agricultural high schools thus established the state or locality must furnish the lands, buildings, and also current funds to provide all the necessary general studies to round out strong courses of study. The only restrictive provisions are that the federal money shall be effectively used for studies relating to agriculture, the mechanic arts, and home economics. Since the money is not sufficient to be applied to the consolidated rural school and to the village school where rural pupils must attend while sleeping in their parents homes, 
that part provided for those who expect to be farmers and farm home-makers is directed to be used in agricultural secondary schools of rather large size. This insures that excellence of equipment and teaching force which will justify the nearly mature farm youth in expending time and money to attend.

The bill further provides that Congress shall appropriate one-fourth the sum received by each agricultural high school for a branch agricultural experiment station to be located at these institutions and requires the state to appro-

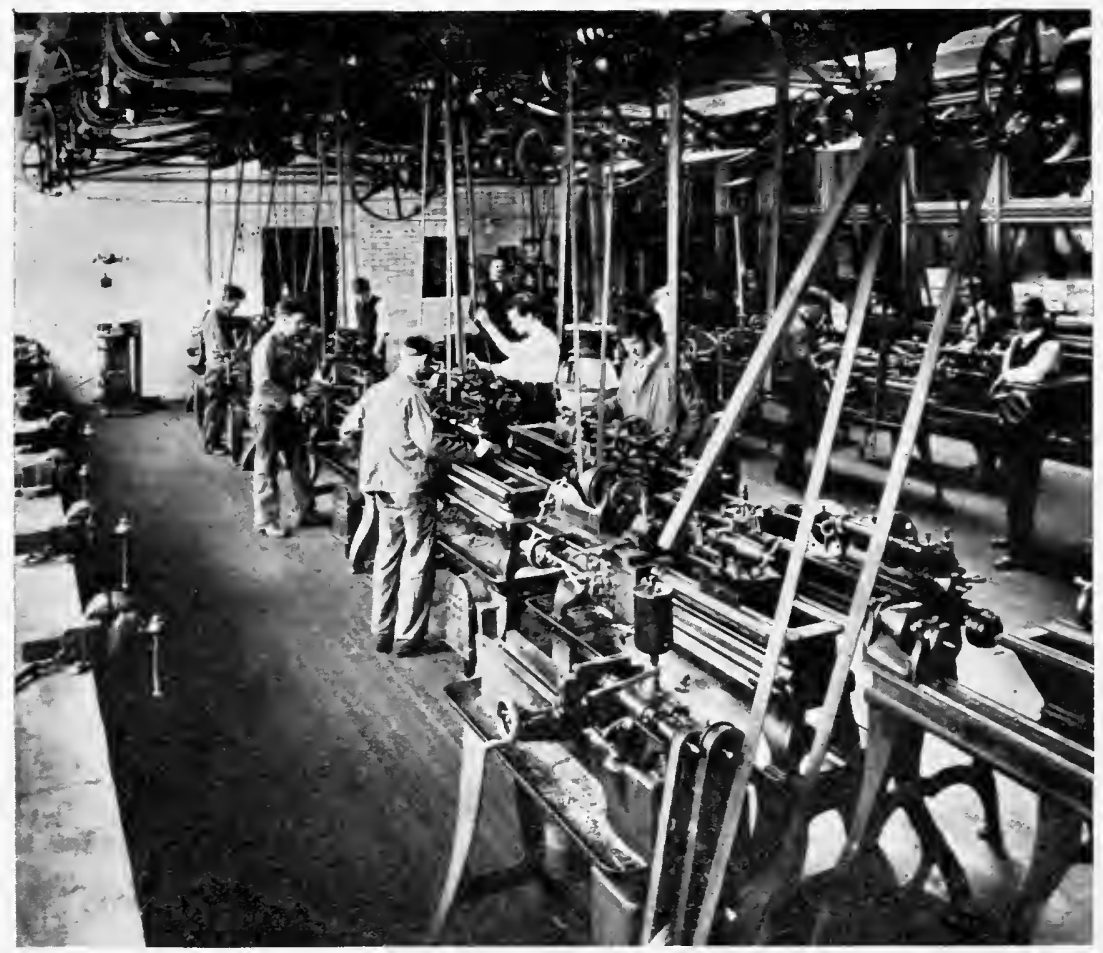

FIG. 29.-Boys in a machine shop, as illustrating work in an engincering college or in a mechanic arts secondary school.

priate an equal sum for these stations. This branch station fund will aid the practical teachers to fully understand the soils, crops, and live stock, and the plan of farm management suited to the respective districts. It will provide means with which to co-operate both with the state experiment station and with the United States Department of Agriculture in breeding, testing, and distributing new rarieties of field, orchard, and garden crops; in improving the $L$ reeds of animals; and in working out systems of farm organization, field management, soil fertilization, and crop production. The assistance these branch stations located in each agricultural district of the entire country would give to the state experiment stations and to the United States Depart- 
ment of Agriculture in enabling them better to do the work of creative breeding, testing, and distributing varieties of plants will, by increasing the values of our crops alone, more than pay the entire sum annually provided by this bill for practical education in city and country.

As a federal measure the ro-county district plan is far more conservative than the plan of establishing one agricultural secondary school and Iranch agricultural experiment station in each county. To really provide one well-

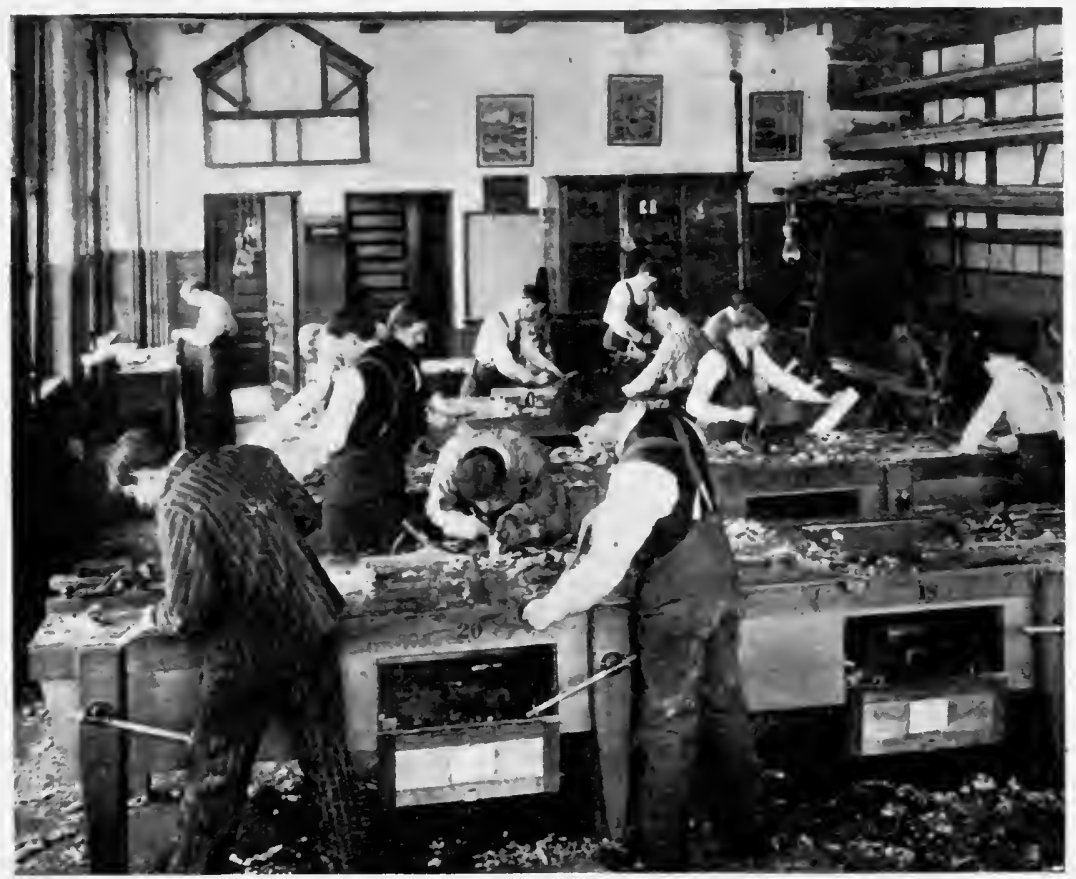

FIr. 30.-Bovs in the school carpenter shop.

equipped school in each county would cost sereral times as much as to equip one in each ro counties. And even yet more expensive would te the plan of using federal money to place agriculture in existing consolidated rural, township, and village schools and in secondary city schools where rural pupils attend. Our rural township and consolidated schools are developing secondary courses. To pay out of the federal treasury for secondary agricultural studies in these schools would mean undertaking to place this instruction where all the pupils could secure it, while yet sleeping at home. The cost would Ie several times the cost under the plan proposed, and thos who, in opposition to the pending bill, propose that alternative surely have not considered the cost to the federal treasury. The mos conservati e plan is to use federal money only to produce leaders and teachers for the proposed larger secondary 
schools and thus to prepare the state and the locality to meet the local expenditure and to manage its home problems.

The ro-county plan provides branch agricultural experiment stations of a size which have proven stable and efficient. Districts of this size provide the needed permanently equipped experiment farm on which the state experiment stations and the federal Department of Agriculture can carry on such longtime and careful work as improving the crops and animals of the respective

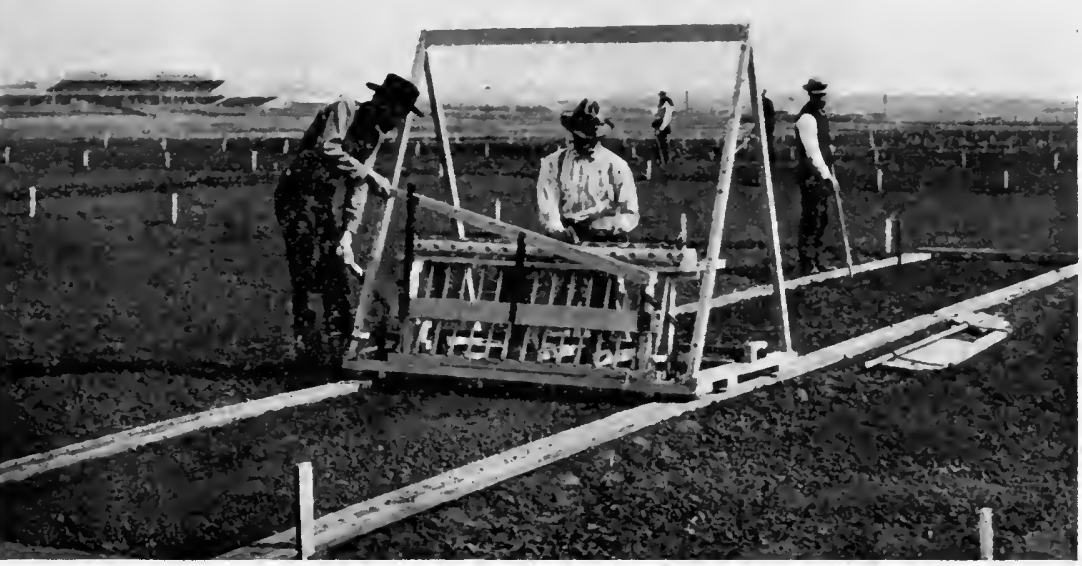

Frs. 3r--Planting wheat by machinery, one seed to a hill, in the plant-breeding nursery, as illustrating work at a state experiment station, at a branch station, or on a private seed farm, where new varieties are being created. Some of the students shown in this picture have become teachers in agricultural colleges and secondary schools and workers in other experiment stations.

states by breeding, and comparing systems of crop rotation, soil fertilization. and farm management.

The consolidated rural school and especially the village school, in which the farm boys and girls begin their courses of vocational training, need the large finely equipped agricultural high school where the secondary vocational course relating to country life can be completed, where both instruction and inspiration will be given. The branch experiment station will articulate with the Io-acre farm of the consolidated rural or village school, and many of the seeds and plants and many of the new ways of doing things developed by departments of agriculture and by experiment stations can be carried by the branch station to the rural school farm and from there thru the pupils to all the farms of the country to which they are respectively adapted. 
This new educational bill, under a plan of restricting the use of federal funds to industrial studies, proposes to broaden, round out, complete and make more effective our entire educational system, alike for city and for country. It will do wonders for our farm boys and girls, for our city youth of all classes, and will start our colored race on a new era of industrial interest, enlightenment and efficiency. Instead of breaking up the unity of our system,

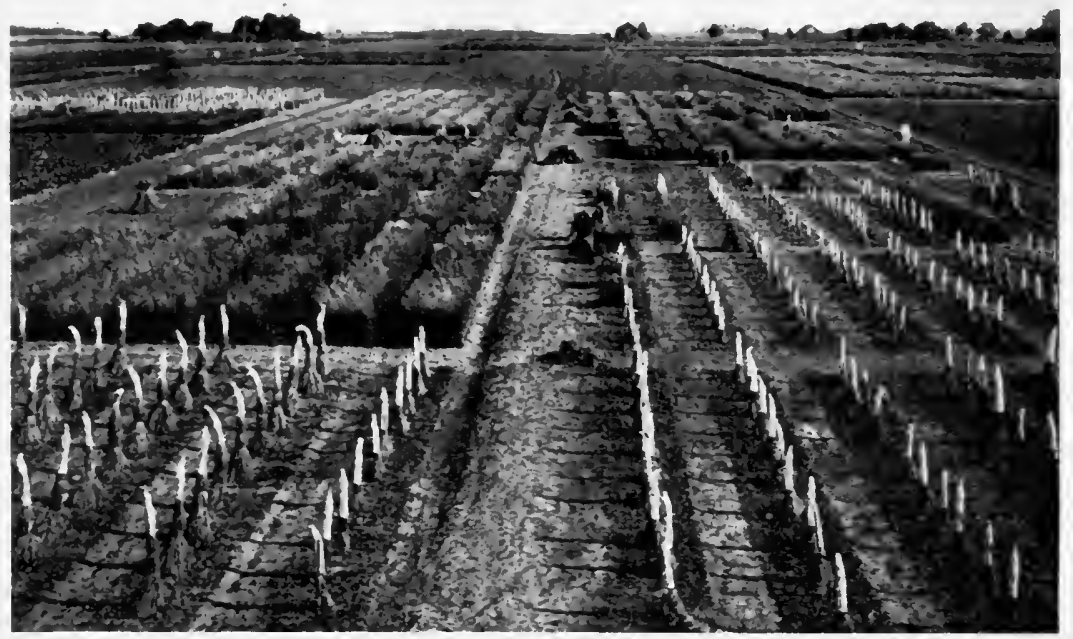

Fig. 32.--Harvesting the plats of grain in the plant-breeding nursery. Fach plat, some of which are shown separately harvested, was planted from the seeds of a single mother plant. The bundle of progeny of each plant while drying is wrapped with muslin to prevent loss by birds. Thus many thousands of new varieties, some of which are from newly hybridized stocks, are tested in a preliminary way as to their power to produce large crojs. Only those yielding very high during three years are chosen for the further field trials, and those succeeding are chosen for distribution to farmers.

it brings about unity by unifying school education with education outside the school. This measure was written in the light of the lessons learned from the administration of the land-grant or state college and the state experiment station acts.

Following such noteworthy examples as the Minnesota, Wisconsin, and Vel,rakka agricultural high schools and branch experiment station organizations, 300 of these institutions would accommodate roo,000 farm boys and girls, most of whom are not seeking an avenue off the farm. Probably 20,000 
would graduate annually, the majority returning to take leading places in their farm communities, a large proportion entering upon teaching as in the consolidated farm schools, in village schools, in normal schools, and in the small district rural schools, and probably io per cent. going to the agricultural college.

Following such splendid examples as the St. Louis, St. Paul, and Washington mechanic arts secondary schools, hundreds of non-agricultural secondary

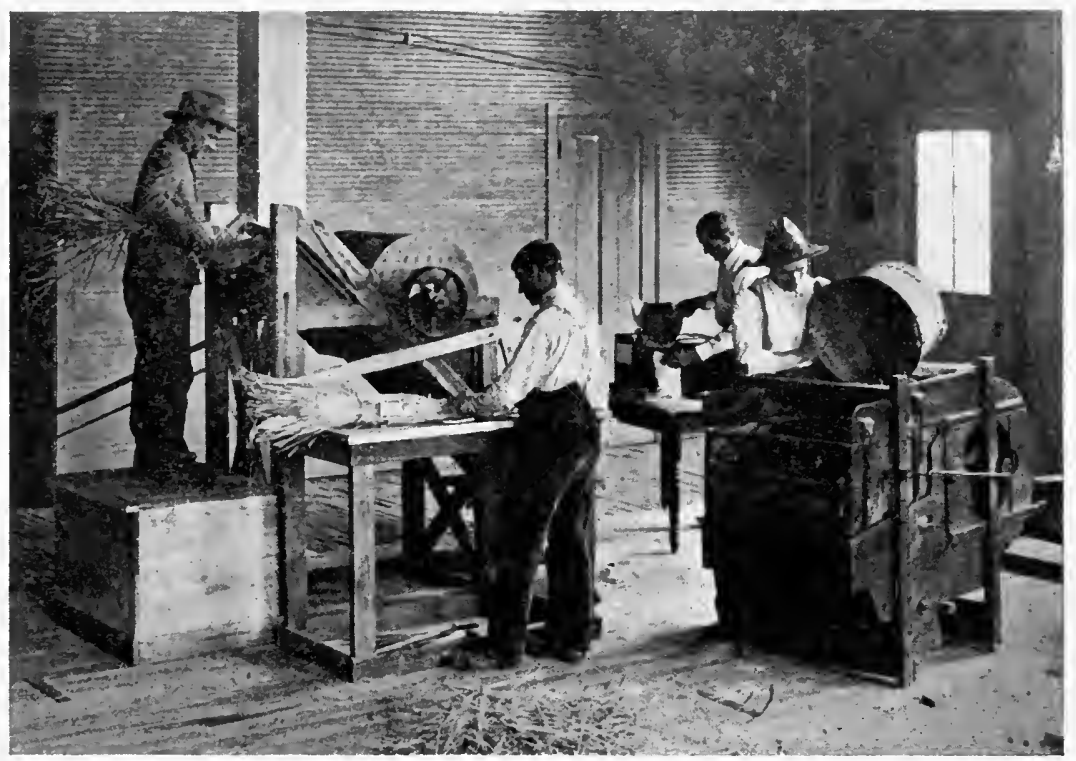

FIG. 33-- Threshing the progeny of each mother wheat plant, to find the blood of those rare mothers which produce heavy-yielding varieties, so that only the very best need be tested in the larger field plats.

schools will accommodate hundreds of thousands of city youth, who wish to pursue courses in mechanic arts, industries, and trades, and girls who wish to have technical training along home-making lines. Tens of thousands will annually graduate and be prepared to rapidly gain high efficiency in the expert trades or in the keeping of homes. Not a few will proceed to the engineering or other technical colleges and the graduates of these schools will eventually grow into leadership of many of our manufacturing and transportation industrial enterprises. But the great majority will take the well-paid places requiring masterful artisans, now too often taken from American youth by highly skilled foreigners. These schools, instead of being places to turn out cheap tradesmen, will supply men who, having joined scientific information, schoolshop experience, and actual service in their chosen trades, will set new standards for our expert trades. Under public management, they will treat fairly both 
the man who has labor to sell and the man who is seeking to employ labor. They will tend to increase wages in these lines; and they will tend to increase the output from labor and to increase the remuneration both of the laborer and the capitalist. Many of the women graduates will splendidly build up the home economics instruction in all schools where girls attend, from primary

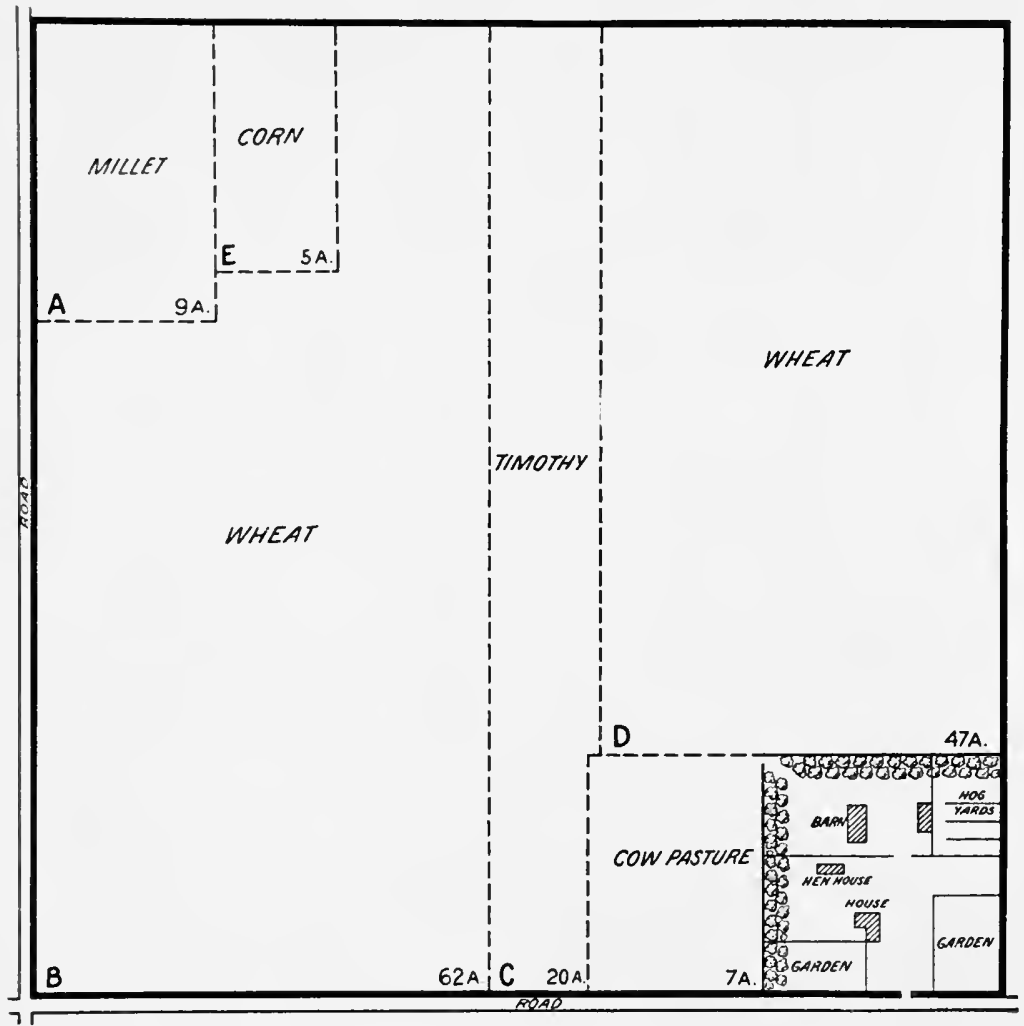

Fig. 34. - The poorly arranged farm. The student in the agricultural high school takes his own home farm for his practice-lesson in farm reorganization. Many are not organized, some are arranged but poorly, while in some cases the arrangement of fields is fairly practical and even scientifically planned. Farm boys soon learn the art of making plans which at once suit their fathers and the teachers.

to collegiate, insuring that the housewives, and mothers of our land be expert in their work. The improvement which will come thru instruction in home economics in the agricultural high schools and in the mechanic arts high schools, will repay all the cost to the federal, state, and local governments required under the provisions of this bill.

Probably the most important feature of the new educational plan in our public-school system is the extension of the school life into the youth's work period: the dovetailing of the school attendance into the entrance upon active 
life. The youth in the secondary course in the consolidated rural school or in the agricultural secondary school devotes alternate six-month periods to school and to the work of the farm. And during the six months out of school the work is made educational by the co-operation of teacher and parents. Likewise, some manufacturing concerns co-operate with the schools,

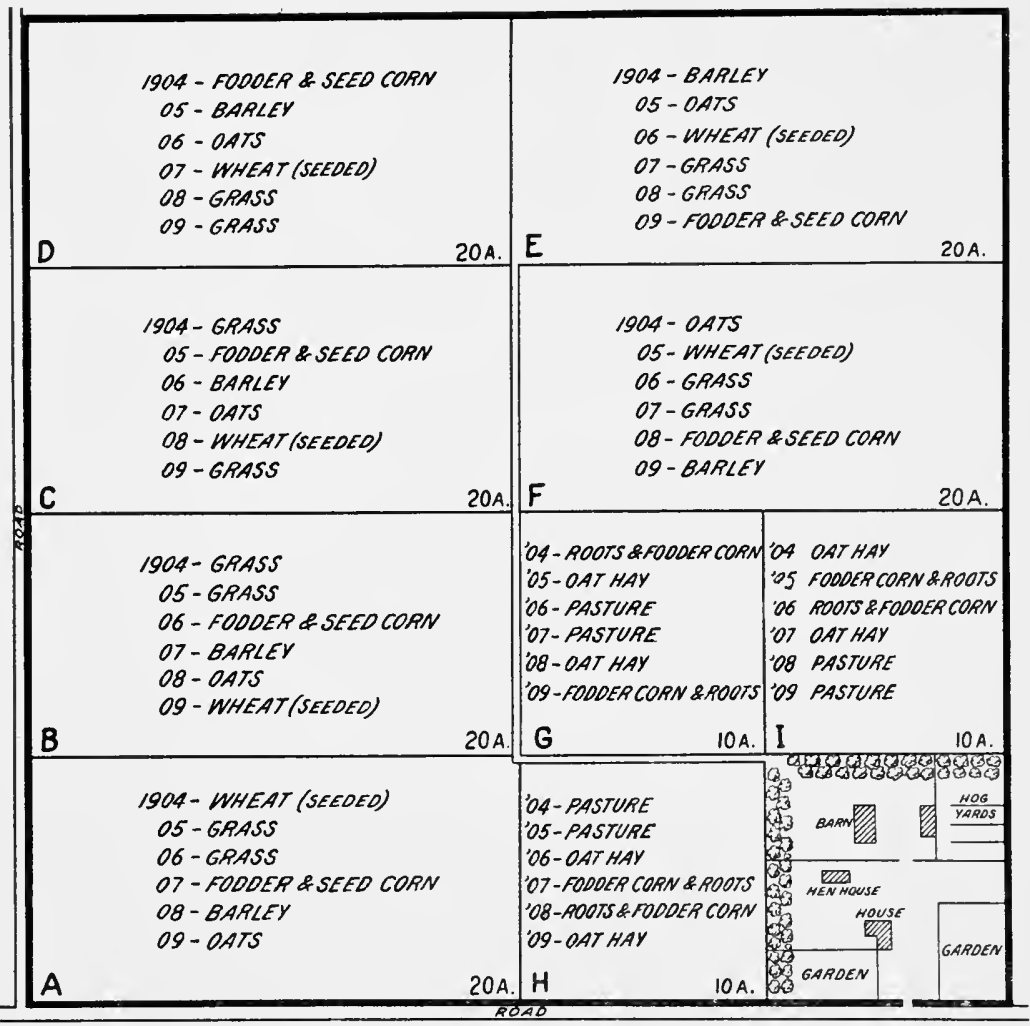

FIG. 35.-Farm reorganized; systematically laid out; with six 20-acre fields devoted to a six-year rotation, and three so-acre fields devoted to a three-year rotation. On branch experiment station farms, numerous schemes of crop rotation and farm management can be tested through decades. The students and farmers can be taught which is best, thru colleges, agricultural high schools, consolidated farm schools, district rural schools, college extension and farmers' institutes, and thru newspapers, bulletins, and books, and especially by means of "demonstration farms," managed by their owners without public aidexcepting aid in making the plan or in gaining an education so as to make it for themselves.

and give the students apprenticeship training one part of the year, taking another group at another season, or the years of work at school and in the apprentice shop are alternated, or even the months or the weeks in school and in the shop are alternated. In some cases the boy's day is divided between the school and the apprenticeship shop. The evening continuation school for those who must "work the whole day is still another form of joining school 
and practical life. General plans need to be wrought out, that the pupil may change from school to real life in a natural way, not easily nor yet too abrupty, nor in a way too strenuous for the development of full physical and mental health.

An arithmetical statement of a completed system of country life educational institutions for a state like Iowa, which is nearly all agricultural, will aid in an understanding of the new movement to give to those who are to farm

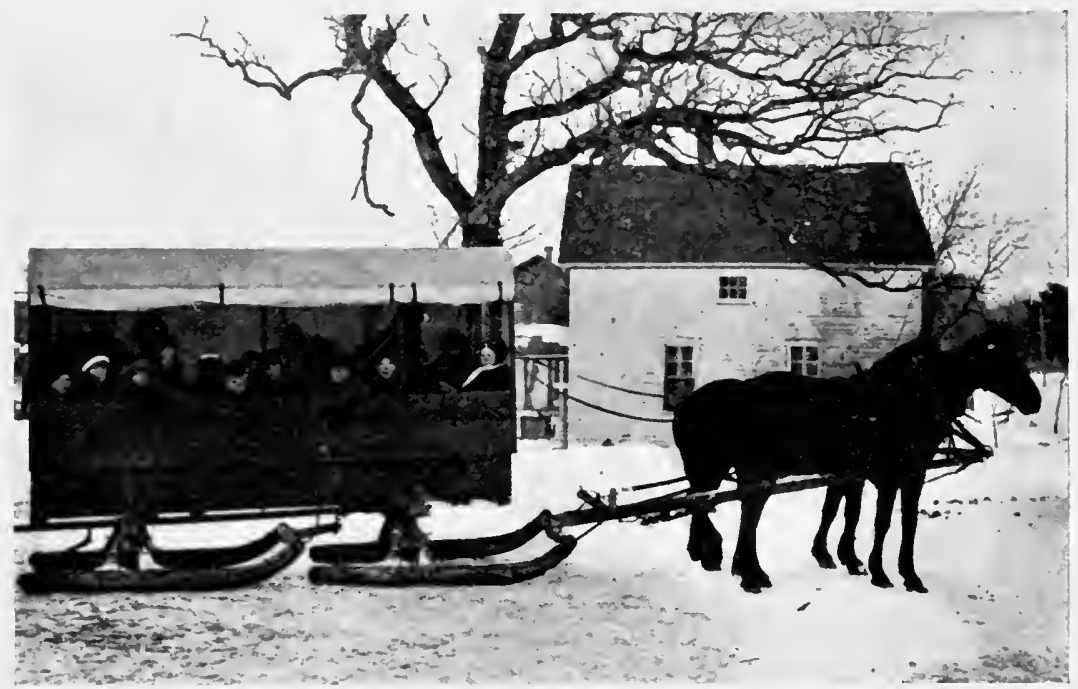

FIg. 36.-Minnesota school wagon near St. Paul. With charcoal foot warmers in the bottom of the sleigh and with blankets, these pupils were hauled + miles when the temperature was as low as 35 degrees below zero, Fahrenheit. The teachers said they reached the school in better condition than pupils who walked less than a mile, and did not require so long to get warm by the stove before beginning study at their desks.

an education at once broad and vocational. Iowa has one agricultural college in the central one of its 99 counties. An agricultural high school in each group of ro counties would provide ro of these schools. Consolidating the I 30 rural schools and the half-dozen village schools of each county into 20 consolidated rural schools and six schools in which the farm and village schools are combined would provide a total for the state of practically 2,000 consolidated farm schools and 600 village, town, and city schools to which rural pupils are hauled by teams. We have thus one agricultural college, ro agricultural high schools at which the pupils must board, and 2,000 consolidated farm schools. It may be assumed that some pupils will go from the village and city schools to the agricultural high school, but that more will go from the farm to the city, general, and special secondary schools, and that for the present purpose the village and city schools may be left out of the general figures. It may be further assumed that each consolidated rural 
school will have 130 pupils, 20 of whom are in the high-school course, for the most part in the first and second high-school years, and I Io pupils in eight primary grades.

A normal proportion of students in the three classes of institutions would then seem to be about as follows: Primary students in 2,000 consolidated rural schools, 220,000; secondary-school students in these 2,000 consolidated rural schools, 40,000; secondary-school students in ro agricultural high schools,

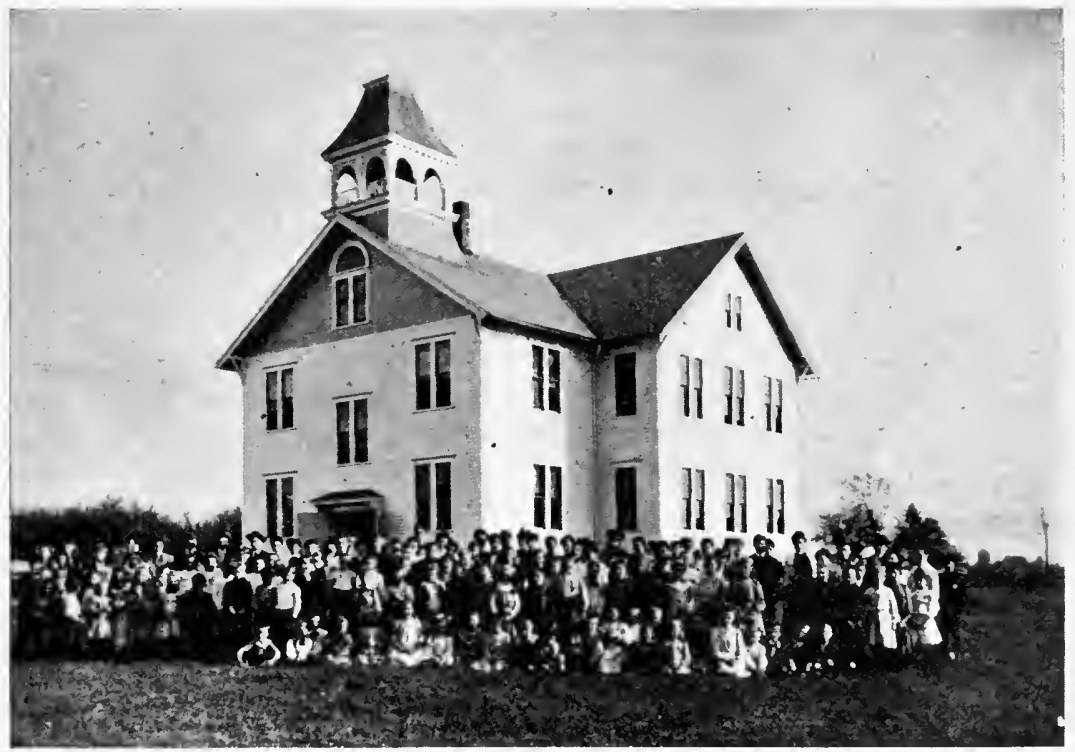

FIG. 37.-Children beside a consolidated rural school. Only a few of the 600 consolidated rural schools, all of which are as yet comparatively new, have established courses in agriculture and home economics. They are properly called "farm schools" only when they are equipped to add these practical subjects to the general school subjects.

4,000; and agricultural collegiate students in the agricultural college, 400 . No doubt many would go from the largest consolidated rural schools directly to the state normal school, while others would attend the agricultural high school before attending the normal, thus to better prepare to teach in the consolidated rural school. Similar figures might be used to show the relation of the city secondary schools articulating with the engineering and other courses in the State University at Iowa City, and in the College of Agriculture and Mechanic Arts, at Ames; also of the agriculture, manual-training, and home economics in the village, town, city, and agricultural schools, to the State Normal School at Cedar Falls.

The bill now before Congress is open to defeat or to improvement and passage. Broadly speaking, it proposes to change our expenditure from say $\$ 4$ per capita to $\$ 4$.ro per capita; and to provide that this added $2 \frac{1}{2}$ per cent. 
of our school expenditure shall be placed under a plan where it can be used only for training in agriculture, in mechanical industries, and in home-making. We all know that this is the side of our educational machinery which has not kept pace with our needs. Some may be willing to take the responsibility of opposing this plan now so auspiciously started, or to load it with other propositions good in themselves but handicaps to the main proposition.

It is of interest to this assemblage of school officials to state that those officials of state normal schools and of state departments of public instruction who are promoting a federal appropriation for normal schools and those interested in securing federal support to secondary industrial education, have each recognized that the two measures represent a single movement and that they should be combined. Already steps are under way to frame a bill around which all can unite in a common movement to put industrial education into our public-school system, wherever and in whatever form local conditions may require. In the secondary schools the studies relating to the industries will be mainly directed toward the preparation of pupils for those agricultural, mechanical, and home-making vocations into which most of them will enter; but in a less direct way these studies will be used to prepare teachers for these subjects. The normal schools, on the other hand, will use the proposed federal funds mainly to prepare teachers in agriculture, manual training, and home economics; but incidentally will add materially to the sum of vocational training, as many of their students will at most teach only temporarily.

The greatest object of education is the uplift of the whole people, the greatest good to the greatest number. But this must be done in large part by the development of leaders. Leaders must not be alone leaders of religion, literature, art, and science. There must be leaders of the community, of the everyday life, of the common work, and of home-making and social intercourse. Our existing schools are rapidly developing along many of these lines. For our industrial communities, secondary schools are needed which will produce many leaders broadly trained to be at once economic and moral leaders and leaders in social and home-making lines. The agricultural high school, with its fidelity to the truths of nature's science, its power-giving along economic and home-making lines, its uplift thru noble school officials, its opportunities for experience in social life and in working in public meetings and in co-operative students' organizations, and with its strong voluntary religious work in Young Men's Christian Associations, and Young Women's Christian Associations, and with its after-hold on its graduates, is a unique and most powerful institution for the production of country life leaders. The city high school, with studies related to the industries and to home-making, and the separate industrial secondary school, also, have great potentialities in the preparation of all-round leaders in the industrial communities of our non-agricultural workers.

Tnis enlarged expenditure for teaching the children of our native and recently arrived Americans how to make better homes and to increase their 
production of commodities has the broadest possible national significance. We are in world competition with nations able and willing to make commodities at lower units of labor charge than we. We must either increase the efficiency of our labor units or be willing to sell them at lower wage prices. America has charge of the world's highest standards of wage and of living. Industrial education has a very large place beside a reasonable tariff in keeping America's dinner pail full. Let us adjust our differences, if indeed we have any, and unite on this broad plan to turn the face of our schools from its too exclusive attention to the splendid traditional studies, and let it shine upon those who work with their hands as it now shines upon the so-called learned professions. Let us try to please all except those who fear to add to the education of the boy and girl studies along the lines of the industrial work in which most of them must earn their bread and purify their hearts by the sweat of their brows.

\section{DISCUSSION}

E. T. FAIRCHILD, state superintendent of public instruction, Topeka, Kans.-To prove all things and hold fast to that which is good is the educational spirit of the hour. Custom and tradition are no longer terms to conjure with in determining the curriculum.

In endeavoring to solve the problem what knowledge and what training is of most worth new tests are being applied. The passive interest of the abstract is being supplemented with the active interest of the concrete. The strong presentment of the necessity and value of the study of agriculture and home economics in the public schools, which we have just heard is in complete accord with the general movement to recognize the other 98 per cent. in our public schools.

It is not so much a question of what, as of how, and when. With more than half of our people engaged in agriculture and home-making, the public has every right to demand that the schools shall train the pupils with a training that shall adapt them to their environment. When we reflect that many states have a rural population of 70 per cent. or more, the need of an industrial training becomes all the more apparent.

The question whether agriculture shall be taught in special schools, such as are contemplated in the Davis bill and such as are in operation in at least three of our states, or whether it shall be attempted in all of our high schools, is a highly important one. While I fully recognize the importance of the measure advocated by Dr. Davis and realize the great impulse such a law would give to agricultural instruction, I cannot but feel that it would be much better if assistance could reach all high schools where agriculture and home economics are taught.

In my own state, Kansas, the Agricultural College is a separate institution and articulates closely with the rural school. With a population of $1,650,000$ we should have but comparatively few schools reaping the benefit of national aid. If pupils are obliged to leave home it would seem that they might with greater profit attend our large and splendidly equipped Agricultural College. I confess to a great deal of sympathy with the argument advanced by Professor Davenport in his address on "The Place of Agriculture in Our American School." Instead of special schools for a special class, let us have strong schools with a sufficient number of courses to meet the varying needs of the student body. Breadth of view, a wider outlook, and a closer understanding and sympathy. with the life-work of others will follow.

The consolidated school will afford much opportunity for instruction in certain 
phases of agriculture, which may easily serve as an incentive to take a more extended course in the high school.

In our state we have a class of high schools that are peculiarly adapted to the introduction of courses in agriculture and home economics. Under what is known as the Barnes law, a favorable vote by any county places all high schools therein, maintaining a four-year course, and preparing fully for the university, in a position where they may be supported wholly by the county at large. At the last general election forty-three of the one hundred and five counties took advantage of this act and today more than eighty high schools are being supported by their respective counties, and forty more high schools are establishing conditions that will render them eligible to like benefits another year. As an equivalent for such county aid tuition is free to all pupils in the county. In addition to these schools some twenty counties have elaborately equipped county high schools, supported by the county.

Both classes of schools are largely supported by the farmers, and it seems peculiarly fitting that agriculture and home economics should be taught therein. It is pleasing to be able to state that excellent courses in these subjects are being offered in several of these schools, and that they are entirely satisfactory to the farmers themselves.

I have said that it is no longer a question of what we shall teach in the high school. This question has gone beyond the stage of debate. The people whose school it is have demanded that the industrial and vocational shall be recognized, and shall have a place in the curriculum. The next step is to see that agriculture and home economics have the same place of importance and availability in the high school that they have in the college.

Lorenzo D. Harvey, superintendent of Stout Manual-Training Schools, Menomonie, Wis.-In the little I may have to say in the present discussion of the general topic, "The Place of Industries in Public Education," I wish first to express my appreciation of the forcible presentation of the subject of agricultural industries and home economics in public schools to which we have just listened. It has presented in a masterful way the arguments for the extension of educational facilities for industrial education. It has shown the possibilities thru the development of the idea of consolidating rural schools and the broadening of their curricula so as to embrace those studies of vital interest to the country boy and girl; and it has outlined an articulated system leading from the home of the child living in the country to the college, while at the same time presenting a course of instruction admirably fitting the child for the active duties of life within his environment.

I must confess that I am not as optimistic as the writer of the paper, concerning the early and general development of the consolidated farm school. The consolidation of rural schools is not a new idea. The six hundred of them now in existence do not present a large showing for more than twenty years of agitation, but their more rapid increase in later years indicates that in the coming years they will increase in number very much more rapidly than in the past. In many states practically nothing has as yet been accomplished. The present systems of school organizations in many of these states make consolidation extremely difficult, while the conservatism of the rural population where any increased expenditure of money is concerned acts as a further cleterrent. Of the six hundred schools now in existence probably not one realizes the ideal which the author of the paper has in mind. It will be many years before that ideal will be realized in a large number of schools. I am not arguing against it. I am simply stating what $\mathrm{I}$ believe to be a fact, for the purpose of emphasizing the idea that not only the plan proposed but all other means of effort looking toward the development of a better system of instruction in rural communities should be utilized to the fullest extent.

The purpose of the Davis Bill as outlined is one which must commend itself to all. I trust it may be so molified that, if it become a law, it shall not operate to fix a single type of secondary agricultural schools for all communities, especially as to area of the 
district which such a school shall serve. I hope the bill may be so modified as to leave to each particular state the distribution of the money appropriated to that state for secondary agricultural schools to such schools as shall furnish proper facilities to a reasonable number of students without regard to the area of the district served.

Upon the general topic, "The Place of Industries in Public Education," I wish to say that while I recognize the importance upon social and economic grounds of the establishment of special vocational schools, I think the problem of industrial education is a much larger one than this. I believe all will agree that with a proper organization of the elementary and secondary school work, the longer pupils can be induced to remain in these schools before entering upon a vocation, the better for them, for society, and for the state.

I should regret to see distinct vocational schools established in such numbers and with the vocational side so emphasized as to present an inducement for children to leave the public schools earlier than they now do, or earlier than is necessary. We hear much of the different types of vocational schools in other countries and especially in Germany. We have much to learn from these countries in the organization of these schools in the United States, but I hope the time will never come in this country when the falling off in attendance of pupils in the public schools shall equal that of Germany as these pupils pass from their thirteenth to their fourteenth year. $U_{p}$ to the thirteenth year practically the entire school population of Germany is to be found in the public schools. In the fourteenth year the number has dropped in many cities of that country to less than ro per cent. of the children of that age. If in school at all, they are in the continuation or trade schools.

In this country manufacturers do not want apprentices at fourteen years of age, and at that age they are not sufficiently mature to do the best kind of work in the preparation for a vocation. In our larger cities it is unquestionably true that many children are of necessity compelled to leave school at an early age, and that the continuation school or the trade school must be provided to meet their needs.

The report of the Massachusetts commission shows that a very large percentage of the children between the ages of fourteen and sixteen in the public schools have not withdrawn from them because of necessity, but because they were not interested in the work which was offered them, or because their parents did not see in it anything which appealed to them as of value in increasing the industrial efficiency of their children.

I believe it is entirely feasible to modify our elementary and secondary courses of instruction in our public schools by the introduction of handwork, so that the work offered will appeal, on the industrial side, to these children and to their parents.

It is argued in some quarters that manual training is in no sense a preparation for industrial efficiency; that its purposes are cultural rather than vocational. I should rather put it that its purposes are both cultural and vocational, and that the work should be so organized as to serve both purposes. It is not a question of what has been or is being done in the way of manual training in this or that public-school system. It is a question of what can be done and what purpose it may be made to serve.

In the acquiring of any trade, I care not what it may be, there are two distinct stages. During the first stage the learner is concerned with finding out the what of each particular process which must be mastered, the how in performing, coupled with the performance of the process under the guidance and control of the attentive mind. During the second stage the learner is occupied in developing skill in the accurate and rapid performance of each particular process and in the correlation of these processes to meet the demands of the shop in which he may be employed. This skill is developed through the repetition of that which at the beginning of this stage he could perform reasonably well when done slowly and with the closest attention to every detail of the doing, continued until the process is performed accurately and rapidly with little mental effort beyond that involved in initiating the motor activity demanded by the process. 
In the statement of the scope and character of work demanded in the first stage, it should be observed that there are three steps in the mastery of any one process: first, the determination of what is to be done; second, the determination of how it is to be done; third, the doing for the accomplishment of the what thru the application of the hoi ${ }^{\prime}$. It must be observed further that the necessary knowledge of the how requisite for the proper performance of the process may not be acquired in advance of any effort in doing, but the learner must have in mind how he proposes to perform any act he regards as necessary in the process before he begins the action. The result of the action may show him that the manner in which he attempted the doing was wrong and that he must revise his conception of the how. But always the knowledge of a how must precede the doing; the doing modifies the how; this modification reacts upon the doing until the proper standard of correctness is reached.

The first stage is one thru which every learner must pass in the mastery of a trade before he can properly enter upon the second stage, during which skill in processes and their use is to be developed, no matter whether the trade is learned in the shop, in the school, or in both school and shop.

This is not the time to discuss the educational principles which determine the place, scope, and character of manual training in the elementary and secondary courses of study for training purposes other than for industrial efficiency. But I venture the assertion that the three steps which characterize the first stage in the mastery of a trade must also characterize every phase of work in a manual-training course which requires an intelligent use of tools and materials in constructive processes, in accordance with sound educational principles. Therefore, it follows that the first stage in the mastery of trade processes, in its rudimentary form at least, is found in all manual-training courses based on sound educational principles and adequate in scope, and that, with proper equipment and competent teaching force, manual training may be extended so as to apply the work of this stage to a considerable number of trades. The second stage may be completed in the shop, in the trade school, or in both.

Manual training in its earlier stages must of necessity be carried on without direct reference or relation to the development of skill in any particular vocation. The training which it gives in close observation of an object to be produced from any given material or as the result of effort in the construction of that object, or determination of wherein the effort has failed and what must be done thru further effort to remedy the failure, the training of the hand to execute mental judgments, furnish a preliminary preparation of high value as a basis for intelligent workmanship which employs the hands later on.

In the later development of manual training it may be so organized as to bear a very definite relation to certain processes largely employed in the industrial world, and at the same time to secure the kind of mental training needed for the proper development of the individual. In a general way it may be said that the following things are essential for industrial efficiency in the workman:

1. Habits of close observation.

2. A high ideal as to what constitutes honesty in workmanship.

3. Habits of accuracy in work.

4. Comprehension of what is good in design as related to use in connection with the work in hand.

5. Knowledge of materials best adapted to different forms and types of construction.

6. Knowledge of construction processes in the treatment of materials.

7. Skill in the care of tools and in their use in industrial processes, and skill in using machinery.

8. Skill in freehand and mechanical drawing.

The foregoing statements are general, but specific applications may be made of them so far as they apply to any particular industrial process or trade.

The practical problem for any community in organizing work in manual training in 
the public schools so that it may bear the most direct and immediate relation to the industrial efficiency of the boys on leaving school is to consider, first, the manufacturing industries of the community where skill in operation is required and which are likely to furnish employment for the boys upon their leaving school; and then to determine the kind of training thru which the boys will make the greatest progress toward skill in the special industry or industries.

In case there are no manufacturing industries in the community in which the school is located, and it is still desired to give training which counts most largely for industrial efficiency within the particular trades or skilled industries which are likely to prove most attractive to the boys of the community, those trades or industries are to be considered.

With the incorporation of a properly organized manual-training course as a part of the work in the public schools, greater inducements to pupils to remain in school will be presented than exist under present conditions; and as a result pupils will remain in school longer, will get a broader training, and in acquiring every one of the eight requisites I have enumerated as essential for industrial efficiency in the workman they will have made some progress, and in all subjects except those in which skill in the use of machinery is considered they will have made very decided advancement. 


$$
\begin{gathered}
\text { Don- perierret } \\
\text { ceres }
\end{gathered}
$$



This book is DUE on the last date stamped below

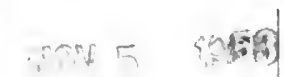

Form L-9-10m-5,'28

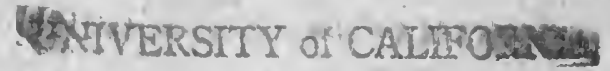 AT LOS ANGELES - LIBRARY}




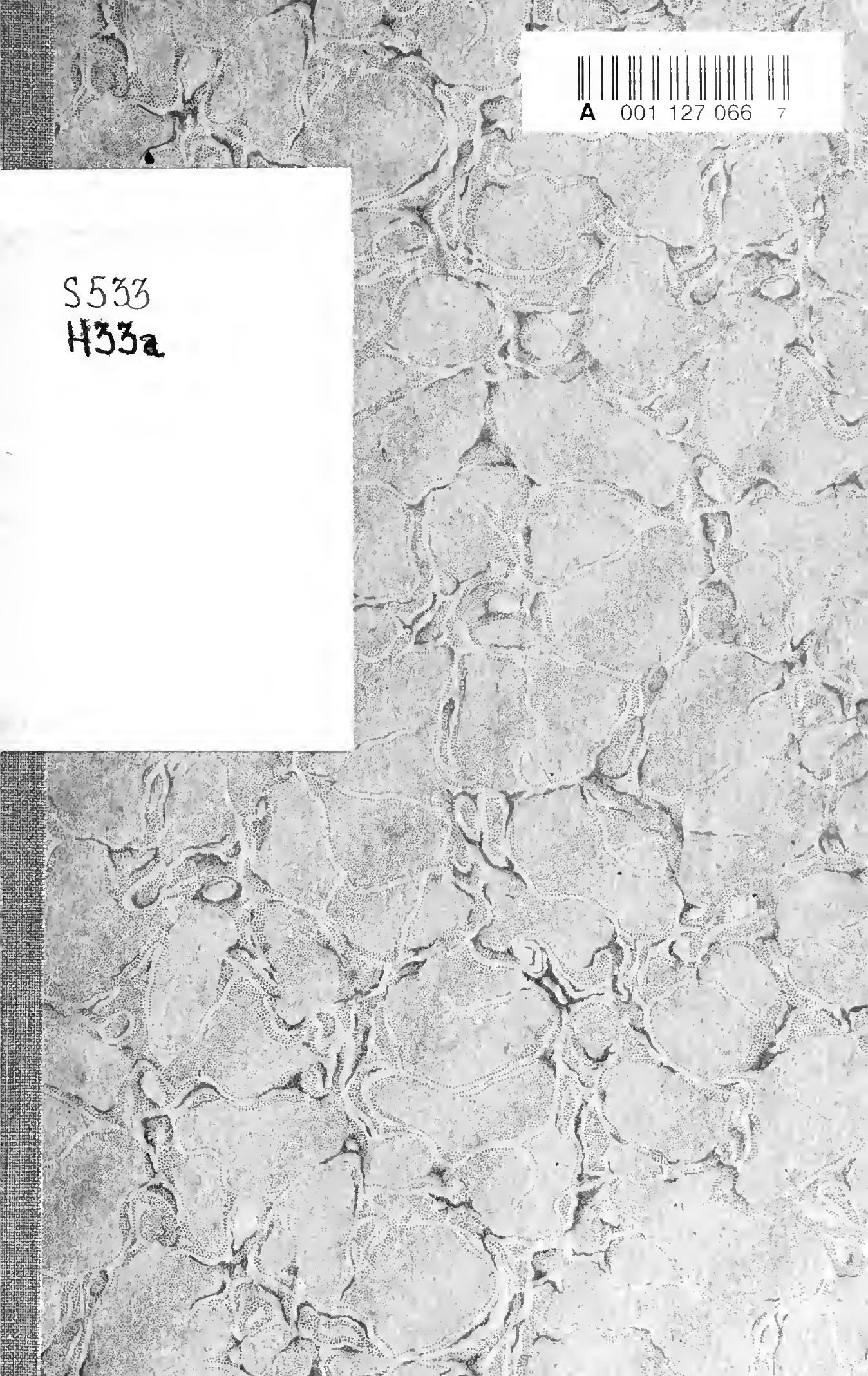




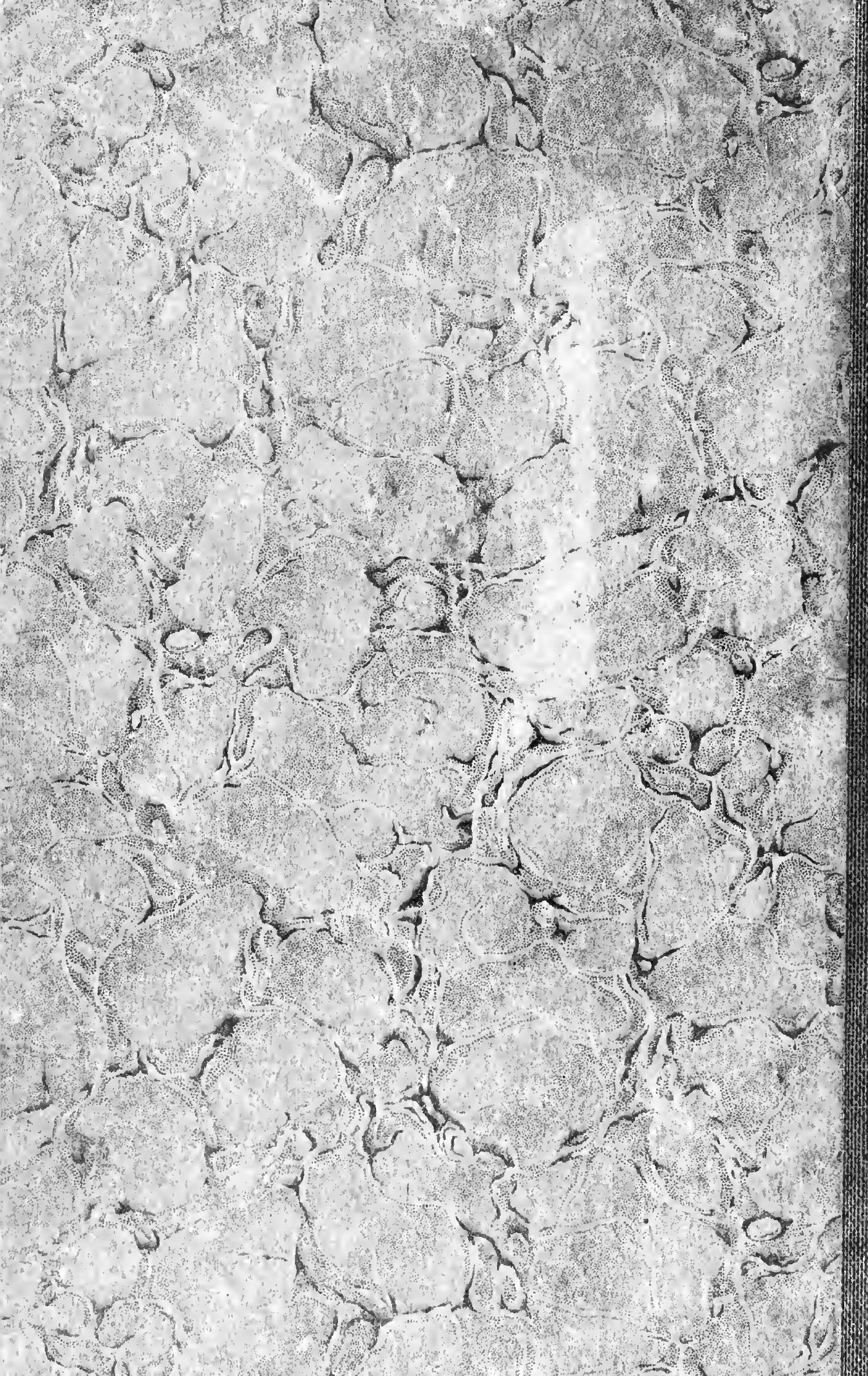

